\title{
Drastic decline of flood pulse in the Cambodian floodplains (Mekong River and Tonle Sap system)
}

\author{
Samuel De Xun Chua ${ }^{1}$, Xi Xi Lu ${ }^{1}$, Chantha Oeurng ${ }^{2}$, Ty Sok ${ }^{2,3}$, and Carl Grundy-Warr ${ }^{1}$ \\ ${ }^{1}$ Department of Geography, National University of Singapore, 10 Kent Ridge Crescent, 119260, Singapore \\ ${ }^{2}$ Faculty of Hydrology and Water Resources Engineering, Institute of Technology of Cambodia, Russian Federation Blvd., \\ P.O. Box 86, Phnom Penh, Cambodia \\ ${ }^{3}$ Laboratoire Ecologie fonctionnelle et environnement, Université de Toulouse, CNRS, Toulouse INP, \\ Université Toulouse 3 - Paul Sabatier (UT3), Toulouse, France
}

Correspondence: Lu Xi Xi (geoluxx@nus.edu.sg)

Received: 17 July 2021 - Discussion started: 21 July 2021

Revised: 19 December 2021 - Accepted: 4 January 2022 - Published: 7 February 2022

\begin{abstract}
The Cambodian floodplains experience a yearly flood pulse that is essential to sustain fisheries and the agricultural calendar. Sixty years of data, from 1960-2019, are used to track the changes to the flood pulse there. We find that minimum water levels over 2010-2019 increased by up to $1.55 \mathrm{~m}$ at Kratie and maximum water levels decreased by up to $0.79 \mathrm{~m}$ at Prek Kdam when compared to 1960-1991 levels, causing a reduction of the annual flood extent. Concurrently, the duration of the flooding season has decreased by about $26 \mathrm{~d}$ (Kampong Cham) and $40 \mathrm{~d}$ (Chaktomuk), with the season starting later and ending much earlier. Along the Tonle Sap River, the average annual reverse flow from the Mekong to the Tonle Sap Lake has decreased by $56.5 \%$, from $48.7 \mathrm{~km}^{3}$ in $1962-1972$ to $31.7 \mathrm{~km}^{3}$ in $2010-2018$. As a result, wet-season water levels at Tonle Sap Lake dropped by $1.05 \mathrm{~m}$ in 2010-2019 compared to 1996-2009, corresponding to a $20.6 \%$ shrinkage of the lake area. We found that upstream contributors such as current hydropower dams cannot fully account for the observed decline in flood pulse. Instead, local anthropogenic causes such as irrigation and channel incision are important drivers. We estimate that water withdrawal in the Cambodian floodplains is occurring at a rate of $(2.1 \pm 0.3) \mathrm{km}^{3} \mathrm{yr}^{-1}$. Sediment decline and ongoing sandmining operations have also caused channel erosion. As the flood pulse is essential for the ecological habitats, fisheries and livelihoods of the region, its reduction will have major implications throughout the basin, from the Tonle Sap system to the Vietnamese Mekong Delta downstream.
\end{abstract}

\section{Introduction}

The Mekong River in Southeast Asia has attracted much attention as water infrastructure development has accelerated in the past years (Best, 2019; Soukhaphon et al., 2021). Due to its transboundary nature, the cross-border hydrological impacts of anthropogenic alterations have become a contentious topic (Stone, 2010). For instance, Keovilignavong et al. (2021) described how the recent 2019-2020 Mekong drought was politicised by states and agencies.

The Cambodian floodplains and the Tonle Sap Lake system is home to a unique geographical phenomenon. During the dry season, the lake empties into the Mekong. However, during the wet season, large tracts of the floodplains are inundated, and flow is reversed from the Mekong to the lake. This annual flood pattern is critical for both the productivity of fisheries (Halls and Hortle, 2021; Sabo et al., 2017; Ziv et al., 2012) and the agrarian communities that are reliant upon the annual floodwaters for replenishment of nutrients and water (Arias et al., 2012; Grundy-Warr and Lin, 2020).

Due to the significance of the annual floods, the ecological and hydrological services provided by the Cambodian floodplains is best understood as a consequence of the flood pulse (Junk et al., 1989). Elsewhere, hydrological alterations to flood pulses have been quantified in the Amazon Basin (Zulkafli et al., 2016) and Missouri Basin (Bovee and Scott, 2002). Within other parts of the Mekong, the flood pulse has been investigated vis-à-vis its relationships to climate (Räsänen and Kummu, 2013; Västilä et al., 2010) and ecosystems 
(Arias et al., 2013; Kong et al., 2017; Ngor et al., 2018). These studies indicate that quantification of flood pulses can be useful in the understanding of the hydrology of a floodplain system.

In the Cambodian floodplains, the water levels in the Tonle Sap Lake and the Mekong mainstream have a close relationship (Guan and Zheng, 2021; Inomata and Fukami, 2008), meaning that any alterations to flows on the mainstream will affect the hydrology of the lake. Studies of the Tonle Sap Lake have predicted that dry-season water levels will increase and wet-season water levels will decrease (Arias et al., 2012; Kummu and Sarkkula, 2008). Indeed, remotely sensed data has confirmed that the surface area of the lake has shown a declining trend since 2000 (Ji et al., 2018; Lin and Qi, 2017)

Overall, the Cambodian floodplains can protect neighbouring Phnom Penh and the Vietnamese Mekong Delta (VMD) downstream from floods by storing large volumes of water during the wet season (Fujii et al., 2003; Mekong River Commission et al., 2004). In addition, the effects of upstream water infrastructure development, such as the Lancang dams, on the VMD are also dampened by the buffering effect of the floodplains (Dang et al., 2015). However, despite its importance, the hydrological changes experienced by the Cambodian floodplains over the past decades have been poorly understood.

This study first aims to quantify the flood pulse along the Cambodian floodplain using sixty years of data, from 19602019. Then, we want to identify the anthropogenic factors that have caused the alterations to the flood pulse. Through this approach, we offer novelty in two ways. First, we studied the Cambodian floodplains in its entirety, as compared to other authors who only investigated the Tonle Sap system (Chen et al., 2021; Kummu and Sarkkula, 2008) or the Mekong system (Binh et al., 2020b). Second, we synthesised knowledge of the various anthropogenic drivers in the Cambodian floodplains and associated them with observed hydrogeomorphological impacts. In so doing, we present the implications of current human activities on the Cambodian floodplains and the wider region.

\section{Study area}

Beginning from Stung Treng, the lower reaches of the Mekong winds through a large floodplain that is seasonally inundated during the wet season (Fig. 1b). Connected to the floodplain is the Tonle Sap system, which expands from an area of $2500 \mathrm{~km}^{2}$ during the dry season to up to $15000 \mathrm{~km}^{2}$ during the wet season (Ji et al., 2018). The whole floodplain is underlain by a mosaic of tropical ecosystems such as gallery forest, shrublands and aquatic herbaceous vegetation (Araki et al., 2007; Arias et al., 2013; Kummu and Sarkkula, 2008), and man-made land use such as rice fields and canals (Mahood et al., 2020; Olson and Morton, 2018). When water level exceeds $12 \mathrm{~m}$ at Kampong Cham, extensive overbank flooding will occur on both banks of the Mekong (Inomata and Fukami, 2008; Mekong River Commission et al., 2004). Concurrently, along the Tonle Sap River, water flows from the Mekong to the Tonle Sap Lake, bringing along its supply of sediment and nutrients (Campbell et al., 2009; Lu et al., 2014b; Siev et al., 2018). In this study, unless otherwise defined, "upstream" refers to stretches of the Mekong located above Stung Treng.

We identify three main anthropogenic factors that can cause changes to the yearly flood pulse: upstream dam construction, irrigation and sand mining. In the Upper Mekong Basin (UMB), the Lancang cascade, consisting of 11 dams over an $800 \mathrm{~m}$ drop, was built by China beginning with Manwan Dam in 1992 (Hecht et al., 2019). These dams have raised concerns due to their ability to alter the hydrological regime downstream (Lu et al., 2014a). For example, the two largest, Xiaowan and Nuozhadu, completed in 2010 and 2014 respectively, have a total reservoir capacity of $38.3 \mathrm{~km}^{3}$, which is more than half of the total capacities of all reservoirs across the whole Mekong Basin (Mekong Region Futures Institute, 2020). The cascade has been found to increase dry-season discharge and reduce wet-season discharge downstream ( $\mathrm{Li}$ et al., 2017; Räsänen et al., 2012) to as far as Kratie (Räsänen et al., 2017). Nearer the Cambodian floodplains, tributary dams such as the Pak Mun Dam in the Chi-Mun system have also been shown to regulate downstream Mekong flows (Cochrane et al., 2014). Dams in the 3S (Sekong, Sesan, Srepok) river basin can also affect the flood pulse downstream by increasing minimum water levels (Arias et al., 2014) or by decreasing wet-season discharge (Piman et al., 2013a).

In recent years, the Cambodian floodplains have been developed to tap into their potential for rice production (Erban and Gorelick, 2016; Yu and Fan, 2011). Under the "Rice-White Gold" policy of the Cambodian government, the country fulfilled its objective to increase rice yield to 4 million tonnes in 2015 from just 20000 tonnes in 2009 (Royal Government of Cambodia, 2010). The boom in rice production was possible with both the use of high-yielding rice varieties and an expansion of irrigation infrastructure that allowed dry-season cropping (Asian Development Bank, $2019 b$ ). With investments from international donors such as the World Bank and the Asian Development Bank (ADB) and countries such as Japan and China, Cambodia has both upgraded its ageing irrigation schemes and constructed new canals and reservoirs (Sithirith, 2017; Table S1 in Supplement). However, this water infrastructure consumes large volumes of water - Erban and Gorelick (2016) estimate that full dry-season irrigation could use up to $31 \%$ of the total Mekong and Bassac flow.

Another anthropogenic activity that has increased pace is sand mining within the river channels (Kondolf et al., 2018; Schmitt et al., 2017). In Cambodia alone, it was estimated that at least 34.4 million cubic metres of sediment 

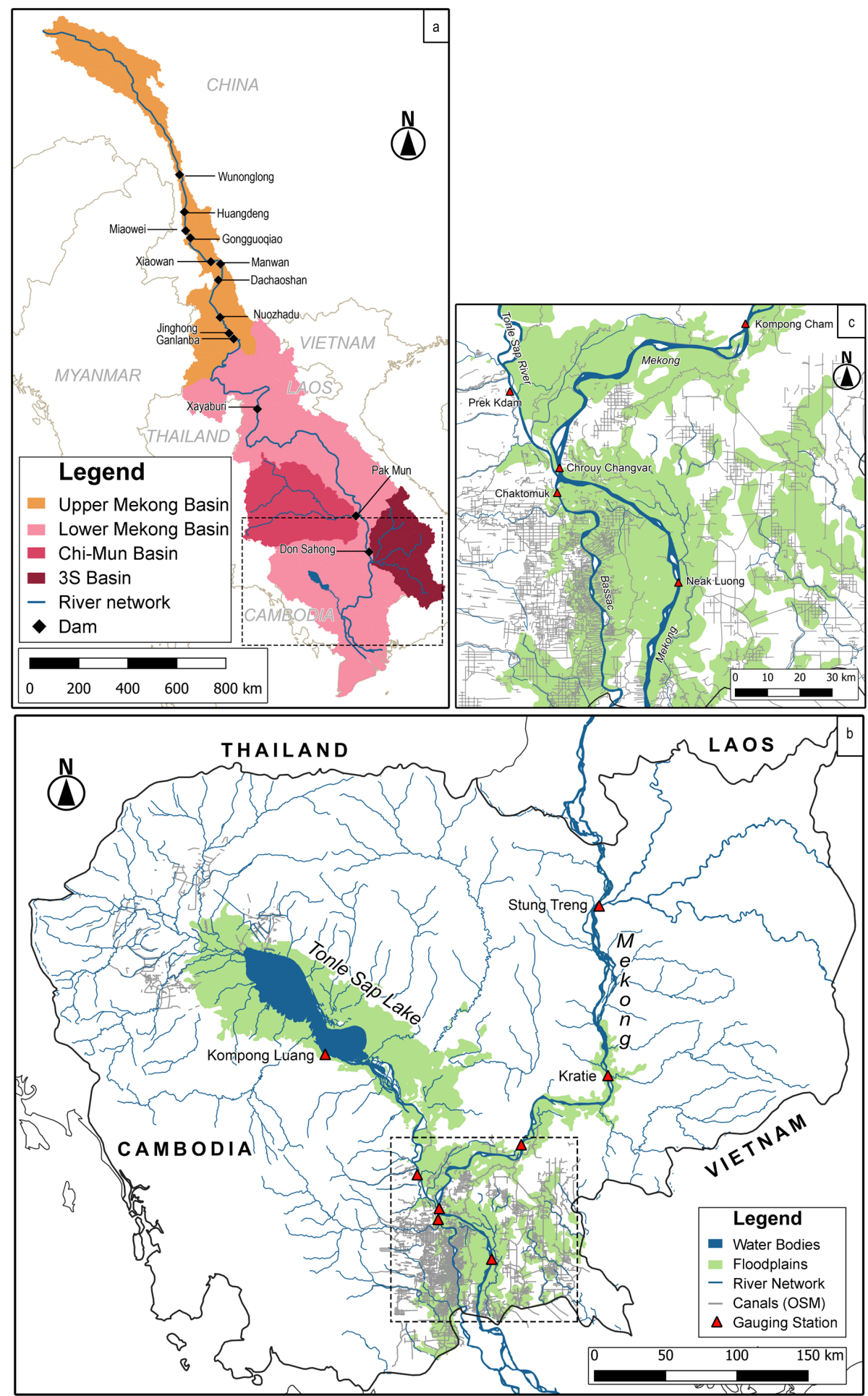

Figure 1. (a) Map of the Mekong Basin showing sites of major mainstream water infrastructure as of 2019. (b) Map of the Cambodian floodplains, beginning from Stung Treng to the Vietnamese border. The floodplains also include the Tonle Sap Lake. (c) Map of the Chaktomuk confluence between the Mekong mainstream, Tonle Sap River and Bassac River. Possible irrigation canals are also shown. The canals in grey are extracted from OpenStreetMap. (C) OpenStreetMap contributors 2022. Distributed under the Open Data Commons Open Database License (ODbL) v1.0. 
were mined per year (Bravard et al., 2013). Of this amount, 18.1 million cubic metres was mined within the short stretch of the Mekong from Kampong Cham to the Vietnamese border (Bravard et al., 2013). As large volumes of sediment are being removed from the river bed, sediment contributions from the Upper Mekong are unable to replenish these losses (Hackney et al., 2020). The problem is so severe in the neighbouring VMD that sand mining has resulted in an up to $1.3 \mathrm{~m}$ decrease in water levels, exacerbating the impacts of sealevel rise and saltwater intrusion (Brunier et al., 2014; $\mathrm{Vu}$ et al., 2018). On the Cambodian side, Hackney et al. (2021) estimate that sand mining has caused riverbed incision at a rate of $-0.26 \mathrm{~m} \mathrm{yr}^{-1}$ from 2013 to 2019 with no signs of abatement. Consequently, Ng and Park (2021) conjectured that this incision is causing the Tonle Sap Lake to shrink.

\section{Materials and methods}

\subsection{Data}

Water level and discharge data were obtained from the Mekong River Commission (Mekong River Commission, 2021). On the Mekong mainstream, we obtained data from Stung Treng, Kratie, Kampong Cham, Chroy Changvar and Neak Luong. We also obtained data from Prek Kdam (Tonle Sap River), Chaktomuk (Bassac River) and Kampong Luang (within Tonle Sap Lake). These stations were selected due to their good coverage of the Cambodian floodplains and documentation of their historical records from 1960 onwards (Table 1).

However, there are some gaps in the digital data downloaded from the MRC data portal. For these gaps, we consulted physical data records at the MRC office and Ministry of Water Resources and Meteorology, Cambodia. While most of these missing entries were found and filled, there are still some years without documentation despite our best efforts (Fig. S1 in the Supplement). Precipitation data were also obtained from the MRC for Kampong Cham and Chaktomuk.

At Kampong Cham, Neak Luong and Chaktomuk, missing discharge data from 2012-2019 were calibrated from their corresponding water levels using the rating curves derived by the Mekong River Commission et al. (2004; Eqs. 1 to 3). To test the validity of these curves, they were used to generate predictions of daily discharge values from 2003-2011. The predictions were then compared with actual discharge readings measured during the same period to obtain their respective $R^{2}$ score. The plots of actual and predicted values are available in Fig. S2 in Supplement.

$$
\begin{aligned}
& \text { Kampong Cham }(\mathrm{KC}): Q_{\mathrm{KC}}=\left(8.869 H_{\mathrm{KC}}+29.811\right)^{2} \\
& \left(H_{\mathrm{KC}}-H_{\mathrm{CC}}\right)^{0.3}+2412.182\left(R^{2}=0.998\right) \\
& \text { Neak Luong }(\mathrm{NL}): Q_{\mathrm{NL}}=\left(12.718 H_{\mathrm{NL}}+62.250\right)^{2} \\
& \left(H_{\mathrm{CC}}-H_{\mathrm{NL}}\right)^{0.2}\left(R^{2}=0.993\right)
\end{aligned}
$$

$$
\begin{aligned}
& \text { Chaktomuk }(\mathrm{CK}): Q_{\mathrm{CK}}=\left(13.943 H_{\mathrm{CK}}+19.992\right)^{1.8} \\
& \left(R^{2}>0.999\right)
\end{aligned}
$$

Here, $Q$ is discharge and $H$ is water levels. $H_{\mathrm{CC}}$ refers to water level at Chroy Changvar.

The high $R^{2}$ scores indicate high accuracy of the predicted discharge values and thus justify their use for further analysis. Additionally, we identified an unreported change in the rating curve at Stung Treng. The new curve was implemented on 1 January 2005 and depressed discharge values afterwards, making them unsuitable for comparison with prior data (Lu and Chua, 2021). Therefore, post-2004 discharge data must be calibrated with the previous rating curve. The previous rating curve was obtained by plotting discharge and water level data from 2000-2004 and then seeking the best fit line with the smallest RMS error. The resulting polynomial relation (Eq. 4) achieved high accuracy with $R^{2}>0.999$ :

$$
\begin{aligned}
& \text { Stung Treng }(\mathrm{ST}): Q_{\mathrm{ST}}=207.549 H_{\mathrm{ST}^{2}}+2598.316 H_{\mathrm{ST}} \\
& \quad-4854.477\left(R^{2}>0.999\right) .
\end{aligned}
$$

\subsection{Methodology}

Figure 2 offers a timeline of major anthropogenic processes occurring in the Mekong Basin from 1960 to 2020. There are three distinct phases of water infrastructure development: 1960-1991, 1992-2009 and 2010-2019. 1960-1991 constitutes the pre-dam era and can be treated as the historical baseline before any major water infrastructure development. Following the construction of the first dam on the Mekong mainstream - the Manwan Dam - the growth era, from 1992 to 2009, saw extensive hydropower development both on the Mekong mainstream and its tributaries upstream in China, Thailand and Laos. For example, during this period, China constructed the Manwan, Dachaoshan and Jinghong dams in the Upper Mekong Basin, with a total storage capacity of no less than $2.95 \mathrm{~km}^{3}$ (Mekong Region Futures Institute, 2020). Within Cambodia, irrigation infrastructure was still small scale and sand mining was only on the scale of 13.5 $\mathrm{Mt} \mathrm{yr}^{-1}$ (United Nations, 2017). However, after 2010, the pace of dam construction increased with the operationalisation of mega-dams in China such as the Xiaowan and Nuozhadu dams, with a combined storage capacity of up to $38.3 \mathrm{~km}^{3}$, thereby marking the start of the mega-dam era (MRFI, 2020). Concurrently, the Cambodian government announced the "Rice-White Gold" policy paper in 2010, sparking a burst of intensive irrigation projects in the Cambodian floodplain (Asian Development Bank, 2019a; Royal Government of Cambodia, 2010). By 2019, the pace of sand mining increased to almost 50.2 $\mathrm{Mt} \mathrm{yr}^{-1}$ (Hackney et al., 2021), almost 4 times its 2009 rate.

This division of our study period into the three eras allows us to view any hydrological changes within the context of wider basin developments in the Mekong. Furthermore, this division is consistent with other studies in the region (Binh 
Table 1. Summary of obtained data records from the various stations.

\begin{tabular}{|c|c|c|c|c|c|}
\hline & & \multicolumn{2}{|c|}{ Actual Data } & & \multirow[t]{2}{*}{ Computed Discharge Data } \\
\hline & & Water Level & Discharge & & \\
\hline \multirow[t]{4}{*}{ Mekong mainstream } & Stung Treng & 1960-2019 & 1960-2019 & 2005-2019 & $\begin{array}{l}\text { Calibrated to } 2000-2004 \text { rating curve } \\
\text { because new rating curve depressed dis- } \\
\text { charge values from } 2005 \text { onwards }\end{array}$ \\
\hline & Kratie & 1960-2019 & $\begin{array}{l}1960-1969 \\
1980-2019\end{array}$ & & \\
\hline & Kampong Cham & 1960-2019 & 1960-2011 & 2012-2019 & $\begin{array}{l}\text { Used the rating curve from the Mekong } \\
\text { River Commission et al. (2004) to esti- } \\
\text { mate discharge for missing years }\end{array}$ \\
\hline & $\begin{array}{l}\text { Chroy Changvar } \\
\text { Neak Luong }\end{array}$ & $\begin{array}{l}2000-2019 \\
1960-2019\end{array}$ & 1960-2011 & 2012-2019 & $\begin{array}{l}\text { Used the rating curve from the Mekong } \\
\text { River Commission et al. (2004) to esti- } \\
\text { mate discharge for missing years }\end{array}$ \\
\hline Tonle Sap River & Prek Kdam & 1960-2019 & $\begin{array}{l}1962-1972 \\
1995-2018\end{array}$ & & \\
\hline Bassac River & Chaktomuk & 1960-2019 & 1960-2011 & 2012-2019 & $\begin{array}{l}\text { Used the rating curve from the Mekong } \\
\text { River Commission et al. (2004) to esti- } \\
\text { mate discharge for missing years }\end{array}$ \\
\hline Tonle Sap Lake & Kampong Luang & 1996-2019 & & & \\
\hline
\end{tabular}

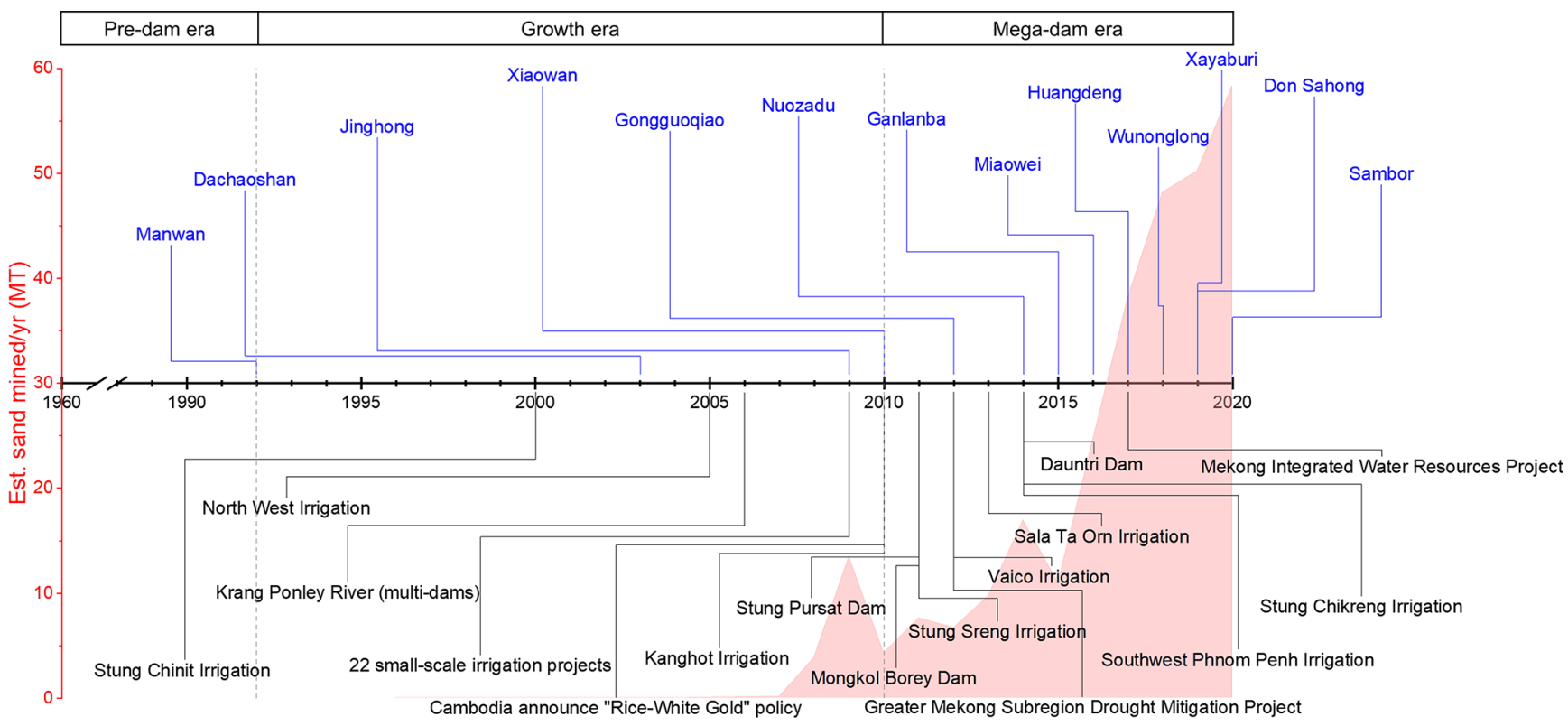

Figure 2. Timeline of major water infrastructure activities in the Cambodian floodplains and the wider Mekong Basin. Blue labels indicate mainstream dams constructed across the Mekong (including the Lancang Cascade). Black labels indicate irrigation projects within Cambodia. The red chart represent the estimated rate sand mined per year in millions of tonnes (Mt). Mining data from 1998-2015 were obtained from the United Nations (2017), while mining data from 2016-2020 were obtained from Hackney et al. (2021). 

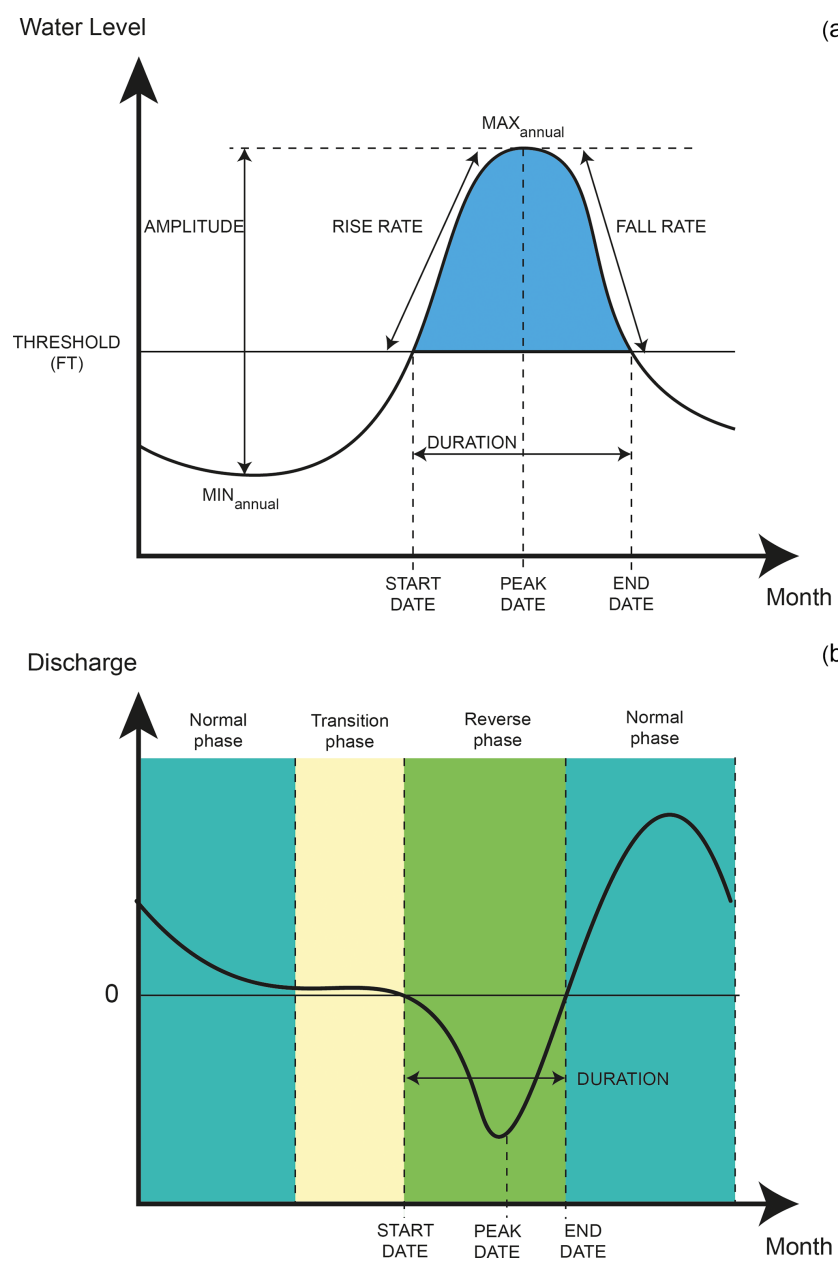

Figure 3. (a) Schematic of flood pulse variables in virtual annual water level plot in the Cambodian floodplains. (b) Schematic of the various phases at Prek Kdam observed through a typical annual discharge plot. Negative discharge values indicate reverse flow from the Mekong to the Tonle Sap Lake.

et al., 2020b; Guan and Zheng, 2021; Li et al., 2017; Räsänen et al., 2017), allowing for the cross-comparison of results. However, due to missing data years at some stations, the study duration might not be consistent. Nevertheless, our analysis still reflects the general trend and central tendency across the different timeframes because only average values were compared.

\subsubsection{Flood pulse}

The various parameters used to characterise flood pulse as seen in Fig. 3a were determined from Eqs. (5) to (14) below.

$\operatorname{MIN}_{\text {annual }}(\mathrm{m})=$ lowest water level of a year

$\operatorname{MAX}_{\text {annual }}(\mathrm{m})=$ highest water level of a year

$\operatorname{AMPLITUDE}(\mathrm{m})=\mathrm{MAX}_{\text {annual }}-\mathrm{MIN}_{\text {annual }}$
THRESHOLD $(\mathrm{FT})(\mathrm{m})=50$ th percentile of all water

levels in study period

START DATE $=$ Date when water level $>$ FT AND

remain more than FT for next $10 \mathrm{~d}$

$\mathrm{END}$ DATE $=$ Date when water level $<$ FT AND

remain less than FT for next $10 \mathrm{~d}$

DURATION $(\mathrm{d})=$ Days between START DATE and END DATE

PEAK DATE $=$ Date of MAX $_{\text {annual }}$

$\operatorname{RISE~RATE}\left(\mathrm{md}^{-1}\right)=\frac{\text { MAX }_{\text {annual }}-\mathrm{FT}}{\text { Days from START DATE }}$

FALL RATE $\left(\mathrm{md}^{-1}\right)=\frac{\text { MAX }_{\text {annual }}-\mathrm{FT}}{\text { Days from PEAK DATE }}$ to END DATE

Comparisons of the means of numerical variables such as AMPLITUDE, RISE RATE and FALL RATE were conducted with Welch's $t$ test. For comparison of dates, the date was first converted to its Julian date. Thereafter, the median date of each study period was compared and validated with a Mann-Whitney test.

\subsubsection{Reverse flow at Prek Kdam}

The parameters used to characterise reverse flow (RF) where water flows from the Mekong to Tonle Sap Lake are stated in Eqs. (15) and (16):

$\operatorname{ANNUALRF}\left(\mathrm{km}^{3}\right)=\sum \mathrm{RF}$ in a year

$\operatorname{MAX}_{\mathrm{RF}}(\mathrm{cms})=$ highest RF of a year

Three phases of the flow pattern are observed: normal phase, transition phase and reverse phase (Fig. 3b). The normal phase is when water flows from the Tonle Sap towards the Mekong. The transition phase begins on the date when the river record water flowing in the reverse direction for the first time in the year. The reversal phase starts when water continues to flow towards the lake and does not switch direction until the water abruptly changes back to the normal phase flow. Note: not all years have a transition phase.

\subsubsection{Discharge changes}

At each station, the mean discharge (in cubic metres per second) from June to September was computed. By comparing average values during the pre-dam and mega-dam eras, the change in flood pulse across the entire Cambodian floodplain can be visualised. Additionally, the difference in discharge $\left(Q_{\text {diff }}\right)$ between the downstream stations of Chaktomuk (CK) and Neak Luong (NL), and the upper station of Stung Treng (ST), was calculated to estimate the amount of water loss/gain in the Cambodian floodplains (Eq. 17).

$Q_{\text {diff }}=\left(Q_{\mathrm{CK}}+Q_{\mathrm{NL}}\right)-Q_{\mathrm{ST}}$ 
If $Q_{\text {diff }}=0$, then it means that the amount of water entering the floodplain system is roughly equivalent to the amount exiting. If $Q_{\text {diff }}>0$, then it means that there is additional water going to the Cambodian floodplains from outside the Mekong mainstream. This addition can come from precipitation or discharge from tributaries. Conversely, if $Q_{\text {diff }}<0$, then it means that water is lost to outside the Cambodian floodplains through diversion or evapotranspiration.

\section{Results}

\subsection{Mekong River mainstream}

\subsubsection{Changes to annual flood extent}

The annual flood extent is given by the yearly maximum and minimum water levels of the Mekong. Compared to the predam era from 1962-1991, minimum water level was higher during the growth era from 1992-2009 (Fig. 4). The trend continued into the mega-dam era (2010-2019) with significant increases recorded at all stations except Chaktomuk (Table S2 in the Supplement). For reference, the minimum water levels were higher by $0.60 \mathrm{~m}$ at Stung Treng, $1.55 \mathrm{~m}$ at Kratie, $0.60 \mathrm{~m}$ at Kampong Cham and $0.10 \mathrm{~m}$ at Neak Luong.

Furthermore, maximum water levels decreased at all stations downstream of Kratie during the mega-dam era as compared to the pre-dam era. For example, Neak Luong and Chaktomuk experienced 0.55 and $0.76 \mathrm{~m}$ drops respectively. Correspondingly, the amplitude of the flood pulse decreased. Comparing records from the mega-dam era to the pre-dam era, the amplitude dropped by $7.9 \%$ at Kratie, $5.6 \%$ at Kampong Cham, $10.6 \%$ at Neak Luong and $8.9 \%$ at Chaktomuk. This observed increase in dry-season minima and decrease in wet-season maxima are consistent with studies in other parts of the Mekong Basin (Binh et al., 2020b; Li et al., 2017; Räsänen et al., 2017), demonstrating that the impacts of water infrastructure development are evident within the Cambodian floodplains.

In practical terms, more areas of the riverbanks are now permanently inundated during the dry season. As the flood amplitude decreases, the annual flood extent is reduced, meaning that some parts of the floodplains are no longer being flooded during the wet season.

\subsubsection{Changes to annual flood duration}

When compared against 1960-1991 records, the flood seasons in 1992-2009 did not show many significant changes. However, the mega-dam era showed greater alterations in flood timing. Downstream from Kratie, flood duration decreased significantly by $26 \mathrm{~d}$ at Kampong Cham, $36 \mathrm{~d}$ at Neak Luong and $40 \mathrm{~d}$ at Chaktomuk. The drastic shortening of the flood season by up to more than a month was caused by both a delay in flood pulse and an early end to the flooding. The delay in the start of the flooding season was observed to increase with further distance downstream. For instance, while the start date was only later by $9 \mathrm{~d}$ at Kampong Cham, it was later by $11 \mathrm{~d}$ at Chaktomuk and $15 \mathrm{~d}$ at Neak Luong. For the end dates of the flood season, it was earlier by $18 \mathrm{~d}$ at Kampong Cham, $25 \mathrm{~d}$ at Chaktomuk and $18 \mathrm{~d}$ at Neak Luong. Thus, for areas downstream of Kratie, the floodwaters have indeed arrived later and receded earlier, resulting in a shorter wet season and a longer dry season.

\subsubsection{Changes to rise and fall rates}

Changes in rise/fall rates reflect influences of upstream water infrastructure. During the rising limb of the wet season, reservoirs have to release the water stored during the dry season in preparation for the incoming water (Richter et al., 1997; Singer, 2007). Also, the presence of irrigation canals increases the conveyance speed of floodwaters across the floodplains, resulting in an increased rise rate. After the wet season, upstream reservoirs and irrigated fields retain water (Cochrane et al., 2014). As flows to the main channel is reduced, the fall rate is correspondingly higher.

At Kampong Cham, Chaktomuk and Neak Luong, both rise and fall rates were observed to increase during the megadam era as compared to the pre-dam era. The largest change in rise rate was observed at Chaktomuk with a $53.8 \%$ increase, from 0.062 to $0.096 \mathrm{~m} \mathrm{~d}^{-1}$. In terms of fall rates, the largest percentage change was observed at Kampong Cham: a $23.8 \%$ increase, from 0.089 to $0.111 \mathrm{~m} \mathrm{~d}^{-1}$. These observed alterations point at anthropogenic hydrological regulation in the region.

\subsection{Tonle Sap system}

\subsubsection{Changes to water exchange at Tonle Sap River}

At Prek Kdam (Fig. 4f), the hydrological changes mirrored those in the Mekong mainstream. Compared against pre-dam records, the mega-dam era saw minimum water levels increased significantly by $0.25 \mathrm{~m}$ and maximum water level decreased by $0.79 \mathrm{~m}$. This resulted in a significant $12.9 \%$ reduction in amplitude - from 8.27 to $7.20 \mathrm{~m}$. Furthermore, the flood duration was shorter by around $20 \mathrm{~d}$. The average start date in the mega-dam era was 10 July, a significant $15 \mathrm{~d}$ delay from 25 June previously during the pre-dam era.

The total annual outflow from the Tonle Sap Lake to the Mekong decreased from $74.54 \mathrm{~km}^{3}$ in $1962-1972$ to $62.81 \mathrm{~km}^{3}$ in 2010-2019 (Fig. 5a and Table S3 in the Supplement). Similarly, the reverse flow from the Mekong to the Tonle Sap decreased from $49.67 \mathrm{~km}^{3}$ in the pre-dam era to only $31.74 \mathrm{~km}^{3}$ in the mega-dam era - a drastic reduction of $56.5 \%$. In addition, the duration of the reverse phase decreased by around $13 \mathrm{~d}$, from $125 \mathrm{~d}$ in $1962-1972$ to $112 \mathrm{~d}$ in 2010-2019. 

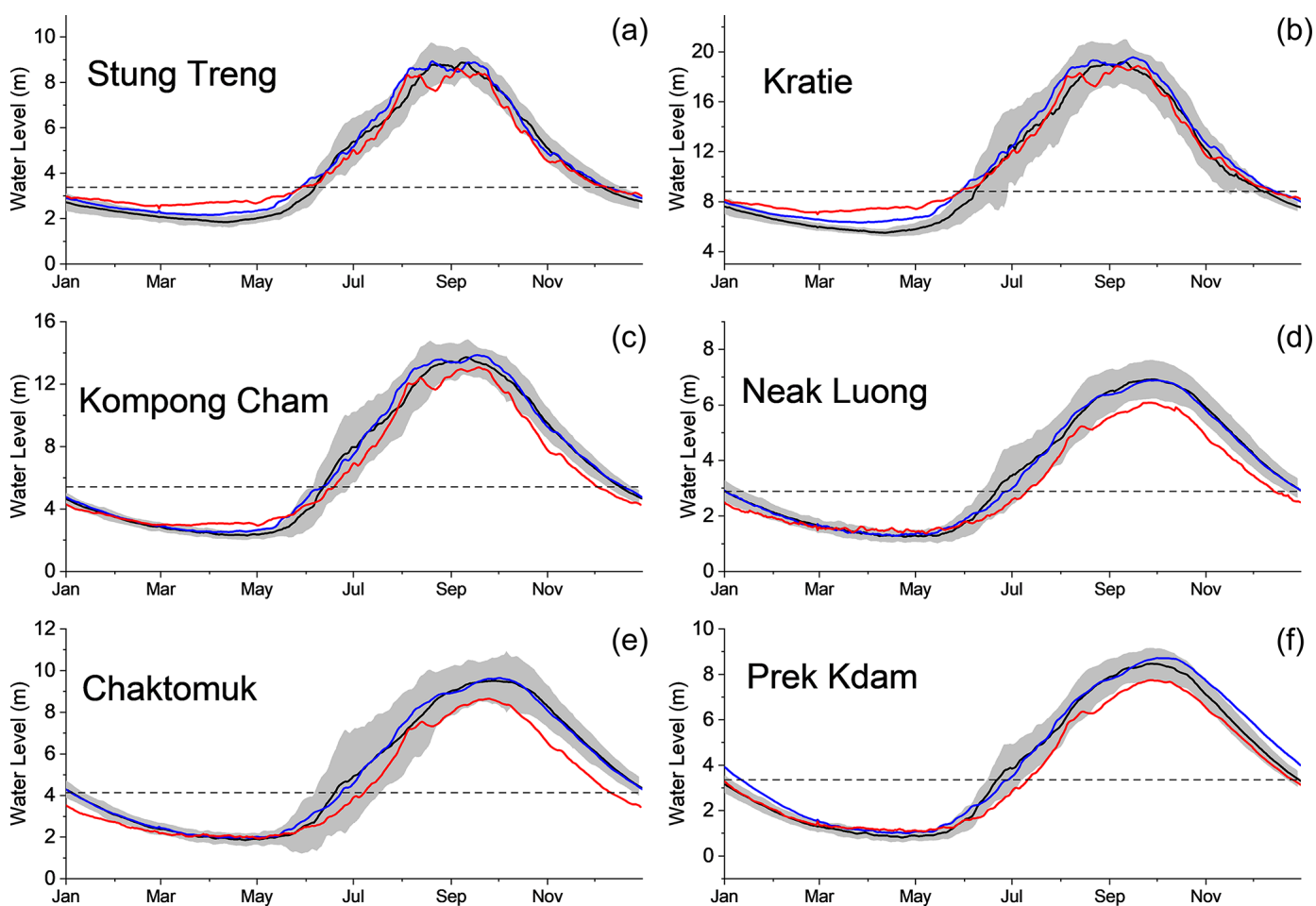

Figure 4. Variation of mean water levels at various stations within the Cambodian floodplains over time. Dotted horizontal line: flood threshold; black curve: water levels from 1960-1991; blue curve: water levels from 1992-2009; red curve: water levels from 2010-2019. Shaded region represents 1 standard error of mean water levels from 1960-1991.
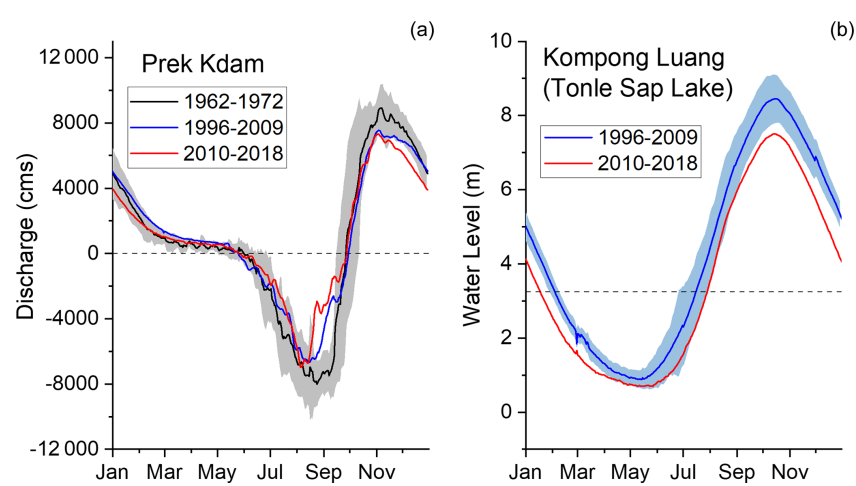

Figure 5. (a) Change in discharge at Prek Kdam over time. Shaded region indicates standard error of mean discharge during 19621972. (b). Change in water level at Kampong Luang over time. Shaded region indicates standard error of mean water level during 1996-2009.

\subsubsection{Changes to Tonle Sap Lake flooding pattern}

At the Kampong Luang station in the Tonle Sap Lake, annual minimum water levels decreased from $0.70 \mathrm{~m}$ in 1996 2009 to $0.60 \mathrm{~m}$ in 2010-2019 (Fig. 5b and Table S4 in the Supplement). Similarly, the yearly maximum water level dropped significantly from $8.58 \mathrm{~m}$ (1996-2009) to $7.52 \mathrm{~m}$ (2010-2019). Using the relation of water level $(H)$ to vol- ume $(V)$ and area $(A)$ as derived by Kummu et al. (2014; Eqs. 18 and 19),

$$
\begin{aligned}
A & =-5.5701 H^{3}+137.40 H^{2}+470.29 H \\
& +1680.2\left(R^{2}>0.99\right) \\
V & =0.7307 H^{2}-0.3554 H+0.9127\left(R^{2}>0.99\right) ;
\end{aligned}
$$

the $1.05 \mathrm{~m}$ drop in the maximum water level meant that $3990 \mathrm{~km}^{2}$ of previously seasonally inundated land is now permanently dry. Correspondingly, the reduction in maximum water volume is a drastic $12.1 \mathrm{~km}^{3}$. This reduction translates to a decrease in $20.6 \%$ of maximum area and $23.4 \%$ of maximum water volume. During the dry season, the minimum area is now $3.1 \%$ smaller (2080 to $2010 \mathrm{~km}^{2}$ ) and contain $5.8 \%$ less water $\left(1.02\right.$ to $\left.0.96 \mathrm{~km}^{3}\right)$.

This observed decrease in both the minimum and maximum water levels is consistent with recent scholars who monitored the change in Tonle Sap Lake area using remote sensing methods (Ji et al., 2018; Lin and Qi, 2017; Wang et al., 2020). However, the observed decrease in dry-season flow does not follow hydro-modelling results that suggest that the water level should be higher during the dry season at the Tonle Sap Lake (Arias et al., 2012, 2014; Kummu and Sarkkula, 2008; Piman et al., 2013b). We postulate that the models adopted might not have considered the development 
of water infrastructure on Tonle Sap Lake tributaries (Asian Development Bank, 2019a).

Additionally, there was a significant drop in flood duration, from 198 to $163 \mathrm{~d}$. This reduction was caused by an early end to the flood season. During 1996-2009, the average end date of the flood season was 31 January but during 2010-2019 the season ended roughly on 18 January, earlier by $13 \mathrm{~d}$. The shortened flooding season follows the same trend as in the Mekong mainstream.

\subsection{Changes to the flood pulse}

Figure 6 shows a schematic of the annual flood pulse on the Cambodian floodplains. During the pre-dam era of 19601991, the discharge at Stung Treng during the wet season was $25500 \mathrm{~m}^{3} \mathrm{~s}^{-1}$. Downstream at Kratie, discharge reduced slightly to $24000 \mathrm{~m}^{3} \mathrm{~s}^{-1}$, which could be caused by overland flooding between Stung Treng and Kratie. From Kratie to Kampong Cham, as additional water arrived from the surrounding watersheds, discharge increased to $27100 \mathrm{~m}^{3} \mathrm{~s}^{-1}$. Thereafter, extensive overland flooding was experienced at the Chaktomuk confluence of the Mekong, Bassac and Tonle Sap rivers. At Prek Kdam, $4270 \mathrm{~m}^{3} \mathrm{~s}^{-1}$ of water flowed to the Tonle Sap Lake. At Chaktomuk and Neak Luong, $2800 \mathrm{~m}^{3} \mathrm{~s}^{-1}$ and $16400 \mathrm{~m}^{3} \mathrm{~s}^{-1}$ of water continued to flow towards the Vietnamese Delta via the Bassac and Mekong rivers respectively.

During the mega-dam era of 2010-2019, there were reductions in wet-season discharge across all stations. At Stung Treng, discharge only decreased by $300 \mathrm{~m}^{3} \mathrm{~s}^{-1}$, a small $1.2 \%$ reduction. At Kratie and Kampong Cham, discharge decreased to 22600 and $21200 \mathrm{~m}^{3} \mathrm{~s}^{-1}$, a larger percentage reduction of $5.8 \%$ and $21.7 \%$ respectively. All subsequent downstream stations also observed lower discharge. Flow towards the Tonle Sap Lake at Prek Kdam dropped from $37.5 \%$ to $2670 \mathrm{~m}^{3} \mathrm{~s}^{-1}$ and discharge at Neak Luong and Chaktomuk decreased to 14800 and $2200 \mathrm{~m}^{3} \mathrm{~s}^{-1}$ respectively.

As seen in Fig. 7, whether $Q_{\text {diff }}$ is positive or negative depends on the time of the year. In the dry months from October to April, $Q_{\text {diff }}$ is generally positive, implying that there is a net contribution of water from the tributaries. Alternatively, in the wet months from June to September, $Q_{\text {diff }}$ is generally negative as water is lost through the increased evapotranspiration from the flooding. This alternating gain-loss pattern is elucidated in Fig. 8.

Figure $8 \mathrm{~b}$ also showed two general trends in $Q_{\text {diff }}$ across time. During 1960-1975, $Q_{\text {diff }}$ showed an increasing trend. However, from 1976-2019, $Q_{\text {diff }}$ decreased significantly at a slope of $-(68 \pm 8) \mathrm{m}^{3} \mathrm{~s}^{-1} \mathrm{yr}^{-1}$. This implied that the Cambodian floodplains have been losing water at a rate of $(2.1 \pm 0.3) \mathrm{km}^{3} \mathrm{yr}^{-1}$.

\section{Discussion}

\subsection{Impacts of upstream dams and precipitation}

Section 4 has demonstrated that the flood pulse has indeed been decreasing across the Cambodian floodplains. However, whether the reduction is caused by upstream dams, climate or local operations is hotly debated. For instance, the claim that Chinese dams have minimal impact on the inundation area of the Tonle Sap by Wang et al. (2020) was refuted in a response letter by Kallio and Kummu (2021). To investigate these competing drivers, we compared the reduction of wetseason discharge across various stations.

Since Stung Treng, the uppermost station of the Cambodian floodplains, only registered a reduction of $300 \mathrm{~m}^{3} \mathrm{~s}^{-1}$, then the cumulative contribution of infrastructure and precipitation in the upper reaches of the Mekong only accounted for $300 \mathrm{~m}^{3} \mathrm{~s}^{-1}$ of discharge. Propagating this $300 \mathrm{~m}^{3} \mathrm{~s}^{-1} \mathrm{de}-$ crease further, the percentage of discharge reduction caused by upstream development versus that by local development can be ascertained. Thus, only $21 \%$ of reduction at Kratie and $5 \%$ of reduction at Kampong Cham could be attributed to the upper reaches (Table 2). Similarly, even though the downstream stations of Prek Kdam, Neak Luong and Chaktomuk also registered declines in discharge, only about $8 \%$ of the flow reduction at these three lower stations could be attributed to development upstream. Furthermore, there were no significant changes to either maximum flood levels or flood duration at Stung Treng (Table S2 in the Supplement).

The changes in $Q_{\text {diff }}$ further support the argument that local factors are more likely to be the main reason for the reduction of flood pulse. The only natural mechanism able to explain the reduction in $Q_{\text {diff }}$ as shown in Sect. 4.3 is that overbank flooding has become more frequent, leading to an increased loss of water through evapotranspiration. However, from the analysis of flood pulse in Sect. 4.1, we have identified that both flooding extent and duration show a decreasing trend. Therefore, the only plausible mechanism for the drop in $Q_{\text {diff }}$ is local diversion of Mekong flows.

Also, as observed in Fig. 9, measured rainfall in the Cambodian floodplains has remained roughly constant from 1960-2019, in line with observations via other sensing methods (Raghavan et al., 2018; Singh and Qin, 2020; Thoeun, 2015). This observation implies that local precipitation is not the driving factor for the reduction in discharge. Thus, the observed reduction of flood discharge in the Cambodian floodplains cannot be attributed solely to either upstream development or natural climatic variability - local anthropogenic factors are likely the main reason.

\subsection{Impacts of water withdrawal}

The scale of irrigation and construction of irrigation reservoirs has been increasing since the Cambodian government announced its "Rice-White Gold" policy with numer- 


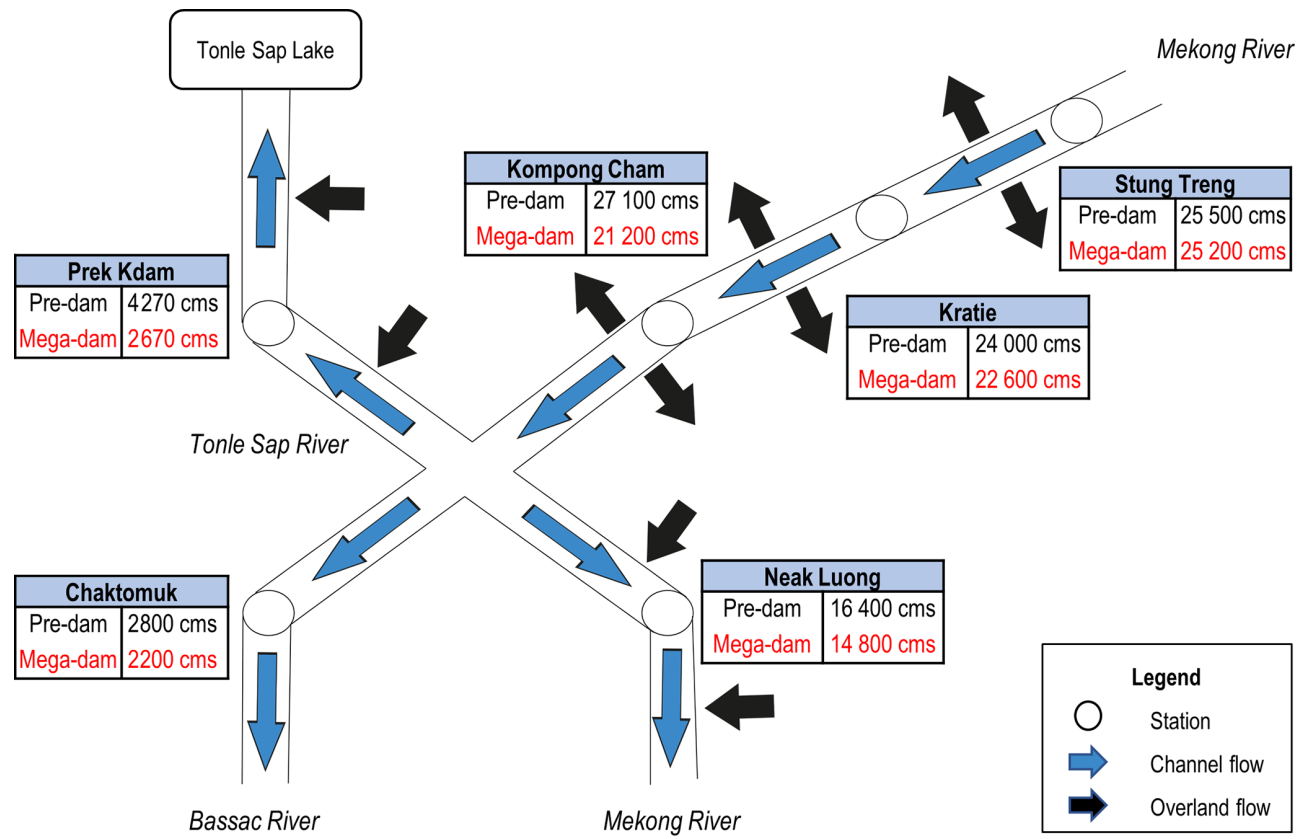

Figure 6. Schematic of wet-season discharge on the Cambodian floodplains during the pre-dam and mega-dam era. Across all stations, there is a reduction of discharge during the mega-dam era of 2010-2019.
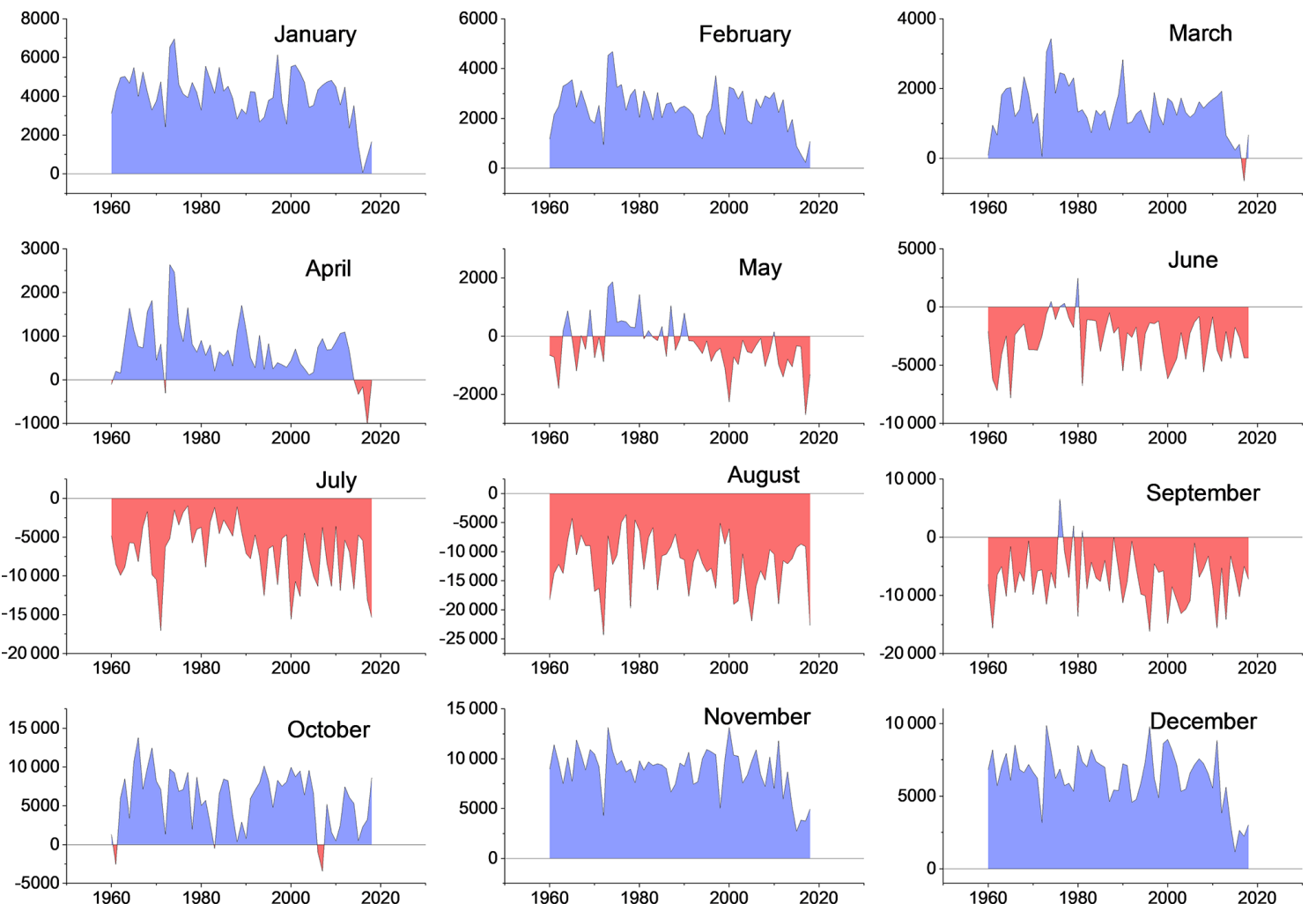

Figure 7. Monthly plots of $Q_{\text {diff }}$ (cms) from 1960-2019. Blue zones indicate $Q_{\text {diff }}>0$, meaning an addition of water from outside the Cambodian floodplains. Red zones indicate $Q_{\text {diff }}<0$, meaning a loss of water to outside the Cambodian floodplains. Generally, during the wet season from June to September, $Q_{\text {diff }}<0$. 
Table 2. Percentage contribution of influences upstream of Stung Treng to the reduction of discharge at the various stations in the Cambodian floodplains.

\begin{tabular}{|c|c|c|c|c|c|c|c|}
\hline & \multicolumn{2}{|c|}{$\begin{array}{c}\text { Wet-season discharge } \\
(\mathrm{cms})\end{array}$} & \multirow[t]{2}{*}{$\begin{array}{r}\text { Total reduction } \\
(\mathrm{cms})\end{array}$} & \multirow[t]{2}{*}{$\begin{array}{r}\text { From upper } \\
\text { reaches }(\mathrm{cms})\end{array}$} & \multirow[t]{2}{*}{ Contribution (\%) } & \multirow[t]{2}{*}{$\begin{array}{l}\text { From Cambodian } \\
\text { floodplains }(\mathrm{cms})\end{array}$} & \multirow[t]{2}{*}{ Contribution (\%) } \\
\hline & Pre-dam & Mega-dam & & & & & \\
\hline Stung Treng & 25500 & 25200 & -300 & -300 & 100 & & \\
\hline Kratie & 24000 & 22600 & -1400 & -300 & 21 & -1100 & 79 \\
\hline Kampong Cham & 27100 & 21200 & -5900 & -300 & 5 & -5600 & 95 \\
\hline $\begin{array}{l}\text { Downstream (Prek Kdam + } \\
\text { Neak Luong + Chaktomuk) }\end{array}$ & 23470 & 19670 & -3800 & -300 & 8 & -3500 & 92 \\
\hline
\end{tabular}

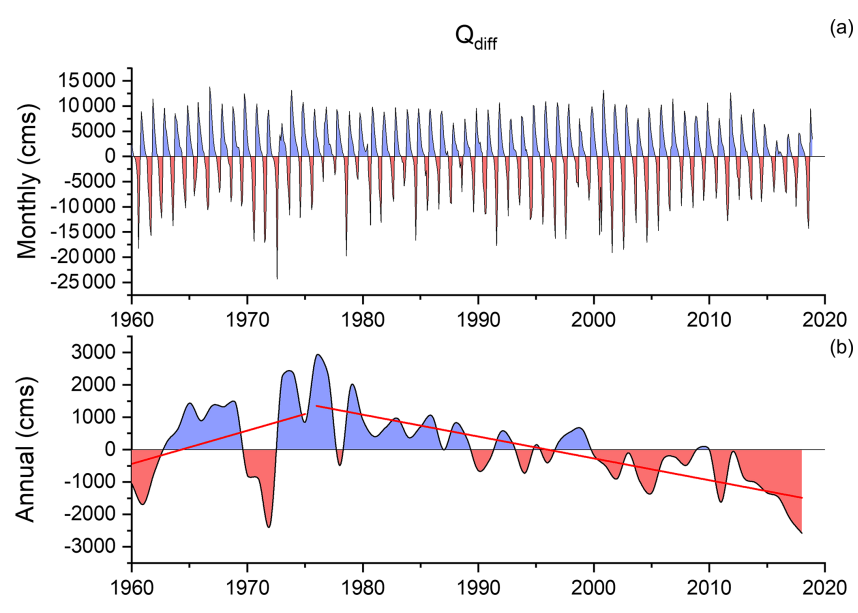

Figure 8. (a) Time series plot of $Q_{\text {diff }}$ from 1960 to 2019 with

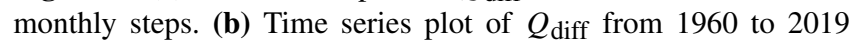
with yearly steps. From 1976-2019, $Q_{\text {diff decreased at a slope of }}$ $-(68 \pm 8) \mathrm{m}^{3} \mathrm{~s}^{-1} \mathrm{yr}^{-1}(p<0.01)$.

ous large projects. For instance, reservoirs have been constructed along the tributaries feeding into Tonle Sap Lake. Further downstream, projects such as the Vaico irrigation project have seen canals constructed across the floodplains east of the Mekong. This infrastructure draws water from the Mekong, resulting in the observed decrease in $Q_{\text {diff }}$.

As Fig. 7 shows, there has been a sharp and obvious decline in $Q_{\text {diff }}$ during November and December from 2010 onwards, coinciding with the start of the Cambodian "RiceWhite Gold" policy. This reduction follows the planting calendar of dry-season cropping from around December to April (Cramb et al., 2020). While the wet-season cropping is primarily rainfed and does not require much diversion of water, dry-season cropping must be extensively irrigated (Mekong River Commission, 2009). Consequently, farmers will store water during the preceding year's wet season for the upcoming second growing season (Phengphaengsy and Okudaira, 2008).

Although irrigation coverage has increased to approximately $22.6 \%$ of paddy land by 2015 , the percentage is still much lower than in neighbouring Thailand and Vietnam (Kea et al., 2016), meaning that Cambodia can still expand its rice production. As drought occurrences are likely to increase in the future (Oeurng et al., 2019), water availability will be the major challenge for the continued expansion of the Cambodian agriculture sector (Bresney et al., 2020; Sithirith, 2021).

\subsection{Impacts of channel incision}

There are two main drivers of channel incision: reduced sediment flux and sand mining. Due to hydropower development in the Upper Mekong Basin, sediment flux has declined in the past decades (Bussi et al., 2021; Kondolf et al., 2014; Kummu et al., 2010; Lu et al., 2014b; Wang et al., 2011). This sediment reduction results in the formation of "hungry water" (Kondolf, 1997), which causes greater erosion of the channels, leading to channel deepening (Kondolf et al., 2018; Lu et al., 2007). Concurrently, sand mining has increased pace within the last decade, with mining areas expanding the most rapidly within the Chaktomuk confluence area at $\mathrm{Ph}$ nom Penh (Hackney et al., 2021). Other areas identified as mining hotspots include the stretch from Phnom Penn to the Vietnamese border along both the Mekong and Bassac channels (Bravard et al., 2013).

Figure 10 shows the relationship between water levels during February at Neak Luong and Chaktomuk, versus that at Kratie. In the absence of man-made hydrological alterations, the water levels at upstream Kratie will be tightly coupled with those at downstream stations throughout the year. However, the water levels at Neak Luong and Chaktomuk have been decreasing with respect to water levels at Kratie. In other words, for the same water level at Kratie, the water level at Neak Luong/Chaktomuk has decreased from the 1960s to 2010s. During February, the changes in mean discharge at Neak Luong and Chaktomuk in the megadam era, as compared to that in the pre-dam era, is $+8.3 \%$ and $-23.3 \%$ respectively - the lowest percentage change among all months. Thus, changes in water level then have a greater contribution from channel incision than from discharge change. 


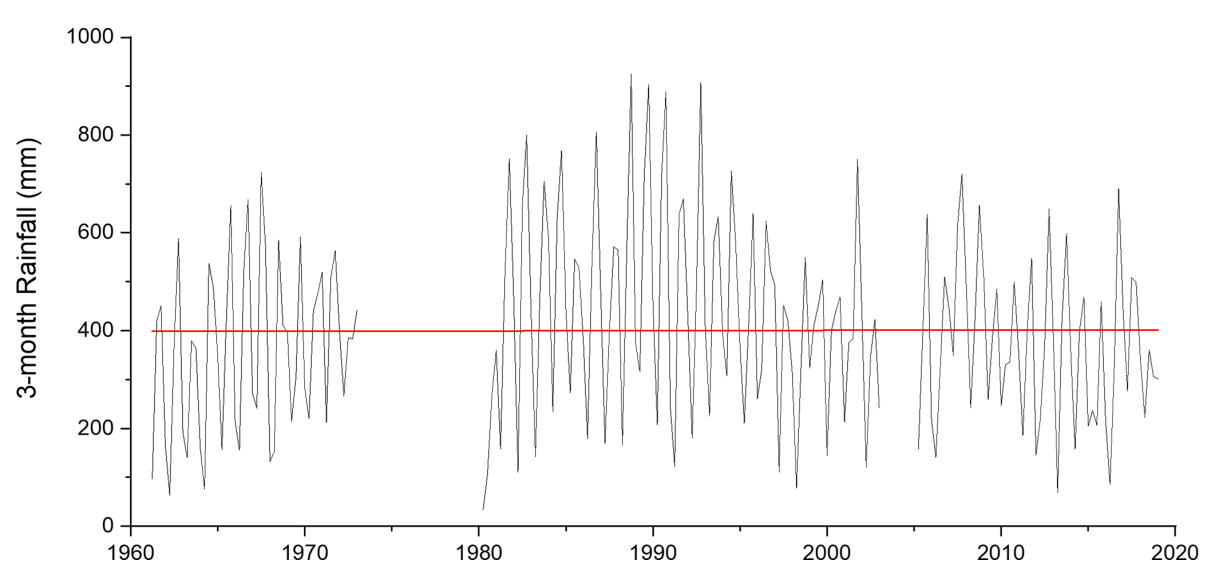

Figure 9. Mean 3-month rainfall at Kampong Cham and Chaktomuk from 1960-2019. There is no statistically significant trend in rainfall within the data period (Mann-Kendall test: $p=0.8$ ).

Neak Luong

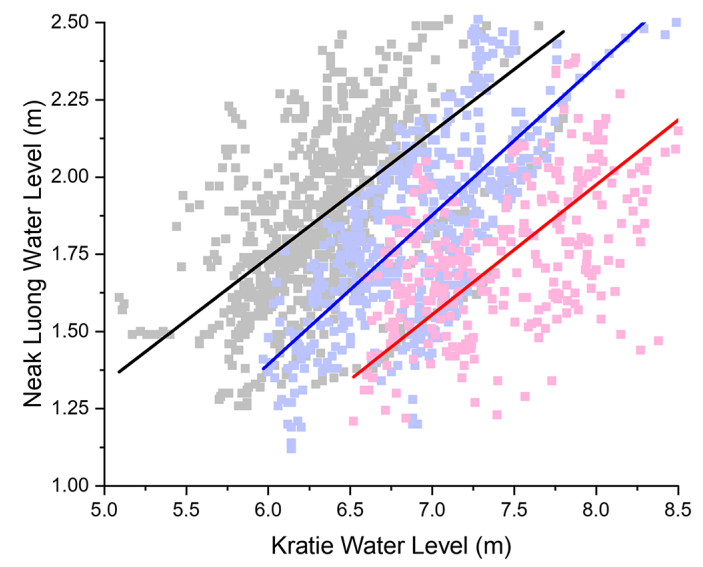

Chaktomuk

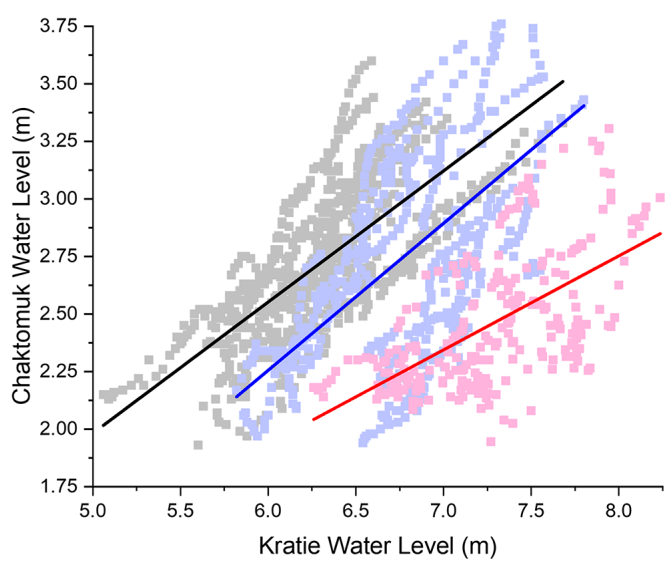

Figure 10. Comparison of water levels at Neak Luong/Chaktomuk against water levels at Kratie during February (black: 1960-1991; blue: 1992-2009; red: 2010-2019). Given the same water level at Kratie, the water levels at Neak Luong/Chaktomuk have been decreasing over time.

The relationship given in Fig. 10 shows that incision at the downstream stations has occurred relatively faster than incision at upstream Kratie. If incision were faster at Kratie, then the $y$ intercept of the best-fit lines would get progressively larger over time, which is not the case. Given a fixed water level of $7.0 \mathrm{~m}$ at Kratie, the water level at Neak Luong has dropped by about $0.60 \mathrm{~m}$ from the pre-dam to megadam era. Similarly, at Chaktomuk, the water level dropped by about $0.79 \mathrm{~m}$. Actual measurements of water level reduction due to sand mining are likely to be higher since the incision at Kratie has not been factored in here. Thus, even without decreases in discharge, channel incision would have contributed to the reduction of water levels, leading to the observed decrease in flood pulse in the Cambodian floodplains.

\subsection{Wider environmental implications}

The Tonle Sap Lake has been decreasing in size throughout the years (Sect. 4.2.2; Kallio and Kummu, 2021; Wang et al., 2020). A parallel can be drawn with Poyang Lake in Yangtze River. There, the Three Gorges Dam has reduced the water level downstream. As the water level was reduced, the hydraulic gradient from Poyang Lake to the Yangtze increased, resulting in a reduction of lake volume there (Zhang et al., 2014, 2015).

In the case of the Tonle Sap Lake, there is a reduction of water levels in the Mekong mainstream during the wet season. As expected from hydrological models (Inomata and Fukami, 2008; Mekong River Commission et al., 2004), the reduced hydraulic gradient from the water levels between the Mekong and the lake leads to lesser water entering the lake from the Mekong. During the pre-dam era, $74.54 \mathrm{~km}^{3}$ of water emptied into the Mekong during the normal flow phase, 
while $49.67 \mathrm{~km}^{3}$ of water entered the lake during the reverse flow phase annually, meaning that there was a net outflow of $24.87 \mathrm{~km}^{3}$. In the mega-dam era, only $68.81 \mathrm{~km}^{3}$ of water flowed into the Mekong during the normal phase and reverse flow decreased to $31.74 \mathrm{~km}^{3}$; net outflow from the lake to the Mekong has increased to $31.07 \mathrm{~km}^{3}$. When comparing the difference in discharge towards the Mekong during the pre-dam and mega-dam era, we see that the average annual outflow increased by $6.20 \mathrm{~km}^{3}$. Without a corresponding increase in inflows from either precipitation or lake tributaries, the lake will decrease in volume over time. Based on reconstructed water level data of Guan and Zheng (2021), we estimated the lake volume during 1960-1990 using the volumestage relation by Kummu et al. (2014). Indeed, compared to the 1960-1990 values, the Tonle Sap Lake volume during 2010-2019 decreased by $35.9 \mathrm{~km}^{3}$, in line with other studies that observed a shrinking of the lake (Ji et al., 2018; Lin and Qi, 2017; Wang et al., 2020).

Downstream of the Cambodian floodplains, the VMD will also be affected by the decreased flood pulse. While hydropower dam operations can increase dry-season water levels (Dang et al., 2016), the combined effects of local channel incision (Binh et al., 2020b) and irrigation operations will reduce dry-season water. Since irrigation infrastructure in the VMD is even more developed than that in Cambodia (Tran and Weger, 2018), the impacts of dry-season extraction is likely to be even greater in the VMD. Therefore, the decreased flood pulse at Chaktomuk and Neak Luong is likely to propagate further downstream to the VMD. Also, a smaller flood pulse will bring fewer sediments to the VMD (Binh et al., 2021). As a result, the current problems of land subsidence and seawater intrusion there may become more severe in the future (Binh et al., 2020a; Kantoush et al., 2017; Zoccarato et al., 2018).

The continued expansion of irrigation and sand-mining operations in the Cambodian floodplains may be unsustainable in the long run. The annual flood pulse is key to regulation of the health of the floodplains, from fisheries to sediment replenishment. For instance, annual floods increase soil health through buffering acidity and increasing its nutrient content (Dang et al., 2016; Sakamoto et al., 2007). A reduction of the flood pulse amplitude and duration will reduce the annual flood extent, thereby reducing soil productivity. Concurrently, as fish migration cycles are intimately tied to the flooding extent, the shift in flood pulse timing will affect catch rates (Baran and Myschowoda, 2009; Enomoto et al., 2011).

\subsection{Limitations and future directions}

Firstly, this study is limited by the hydrological data available. For example, the water level data at Kampong Luang (Tonle Sap Lake) are only available from 1996 onwards, hampering efforts to understand the hydrology of the lake during the pre-dam era. Secondly, in light of channel incision caused by sand mining and other anthropogenic activities, the stage-discharge relationship at several key stations such as Neak Luong and Chaktomuk should be maintained more frequently. Otherwise, regular bathymetry surveys should be done to assess the rate of channel incision more accurately in the area. Thirdly, given the complex hydrology in the Cambodian floodplains, sensors should be installed along the canals or at key intersections in the floodplains. This way, overland flow - a poorly quantified variable - can be monitored and subsequently be included within more complex hydrological models.

\section{Conclusion}

By using 60 years of data from numerous stations across the floodplains, this study quantified that the flood pulse at the Cambodian floodplains has indeed changed drastically in the past decade. Compared to 1962-1991 levels, minimum water levels in 2010-2019 increased by $0.10 \mathrm{~m}$ (Neak Luong) and $1.55 \mathrm{~m}$ (Kratie). As a result, the flood amplitude decreased by $5.6 \%$ (Kampong Cham) to $12.9 \%$ (Prek Kdam), meaning that the annual flood extent diminished. Furthermore, the flood season has decreased by $26 \mathrm{~d}$ (Kampong Cham) and $40 \mathrm{~d}$ (Chaktomuk), with the flood season starting later and ending much earlier.

Correspondingly, the altered flood pulse along the Mekong mainstream affected the annual reverse flows along the Tonle Sap River. At Prek Kdam, total annual reverse flow dropped from $48.67 \mathrm{~km}^{3}$ in $1962-1972$ to $31.74 \mathrm{~km}^{3}$ in $2010-2018$, representing a dramatic drop of $56.5 \%$. Correspondingly, the Tonle Sap Lake has also been altered by this huge change. There, minimum and maximum water levels have dropped by 0.10 and $1.06 \mathrm{~m}$ respectively. These reductions correspond to a decrease in lake area of $3.1 \%$ in the dry season and $20.6 \%$ during the wet season.

These figures were put into perspective as we considered various possible anthropogenic drivers for the hydrological change. We showed that it is unlikely that upstream dams are the main contributing factor for the decline in flood pulse. Instead, the hydrological alterations are more likely to be caused by local factors. The boom in irrigation infrastructure in the last decade has resulted in more water being diverted away from the Mekong and Tonle Sap Lake to the fields. We estimate that an average of $(2.1 \pm 0.3) \mathrm{km}^{3}$ of water was lost per year from the Cambodian floodplains from 1976-2019. Additionally, declining sediments combined with sand-mining operations have caused further channel erosion. Together, irrigation and channel incision has contributed to the observed reduction in flood pulse at the Cambodian floodplains.

As the hydraulic gradient governing the reverse flow to the Tonle Sap Lake decreases, the lake may suffer a permanent reduction in water volume. Furthermore, the impacts of the runoff reduction will be felt further downstream in the 
VMD. This identified shift in flood pulse is non-trivial, with far-reaching ecological and environmental impacts across international borders. Therefore, policy planners must consider the long-term impact of their plans such that the harvesting of the Mekong can be conducted sustainably.

Data availability. Hydrological data are open source and can be downloaded from the MRC data portal at https://portal.mrcmekong. org/home (Mekong River Commission, 2021). Precipitation data used in this study were also obtained from the MRC portal.

Supplement. The supplement related to this article is available online at: https://doi.org/10.5194/hess-26-609-2022-supplement.

Author contributions. SDXC: conceptualisation, data curation, formal analysis, methodology, writing - original draft, writing - review and editing. LXX: conceptualisation, data curation, methodology, writing - review and editing, funding acquisition. CO: data curation, methodology, writing - review and editing. TS: data curation, methodology, writing - review and editing. CGW: writing - review and editing.

Competing interests. The contact author has declared that neither they nor their co-authors have any competing interests.

Disclaimer. Publisher's note: Copernicus Publications remains neutral with regard to jurisdictional claims in published maps and institutional affiliations.

Special issue statement. This article is part of the special issue "Socio-hydrology and transboundary rivers". It is not associated with a conference.

Acknowledgements. We want to thank the Mekong River Commission (MRC) for access to the hydrological data. We want to thank the Ministry of Water Resources and Meteorology, Cambodia for their support. Also, we would like to thank our three anonymous reviewers and editor Fuqiang Tian for their insightful comments. This study was supported by the National University of Singapore (R-109-000-227-115; R-109-000-273-112).

Financial support. This research has been supported by the National University of Singapore (grant nos. R-109-000-227-115 and R-109-000-273-112).

Review statement. This paper was edited by Fuqiang Tian and reviewed by three anonymous referees.

\section{References}

Araki, Y., Hirabuki, Y., Powkhy, D., Tsukawaki, S., Rachna, C., Tomita, M., and Suzuki, K.: Influence of Large Seasonal Water Level Fluctuations and Human Impact on the Vegetation of Lake Tonle Sap, Cambodia, in Forest Environments in the Mekong River Basin, edited by: Sawada, H., Araki, M., Chappell, N. A., LaFrankie, J. V., and Shimizu, A., Springer, Japan, 281-294, Tokyo, https://doi.org/10.1007/978-4-431-46503-4_26, 2007.

Arias, M. E., Cochrane, T. A., Piman, T., Kummu, M., Caruso, B. S., and Killeen, T. J.: Quantifying changes in flooding and habitats in the Tonle Sap Lake (Cambodia) caused by water infrastructure development and climate change in the Mekong Basin, J. Environ. Manage., 112, 53-66, https://doi.org/10.1016/j.jenvman.2012.07.003, 2012.

Arias, M. E., Cochrane, T. A., Norton, D., Killeen, T. J., and Khon, P.: The Flood Pulse as the Underlying Driver of Vegetation in the Largest Wetland and Fishery of the Mekong Basin, Ambio, 42, 864-876, https://doi.org/10.1007/s13280-013-0424-4, 2013.

Arias, M. E., Piman, T., Lauri, H., Cochrane, T. A., and Kummu, M.: Dams on Mekong tributaries as significant contributors of hydrological alterations to the Tonle Sap Floodplain in Cambodia, Hydrol. Earth Syst. Sci., 18, 5303-5315, https://doi.org/10.5194/hess-18-5303-2014, 2014.

Asian Development Bank: Irrigated Agriculture Improvement Project: Report and Recommendation of the President, available at: https://www.adb.org/projects/documents/cam-51159-002-rrp (last access: 1 July 2021), 2019a.

Asian Development Bank: Kingdom of Cambodia: Preparing the Irrigated Agriculture Improvement Project, available at: https://www.adb.org/sites/default/files/project-documents/ 51159/51159-001-tacr-en.pdf (last access: 1 July 2021), 2019 b.

Baran, E. and Myschowoda, C.: Dams and fisheries in the Mekong Basin, Aquat. Ecosyst. Health, 12, 227-234, https://doi.org/10.1080/14634980903149902, 2009.

Best, J.: Anthropogenic stresses on the world's big rivers, Nat. Geosci., 12, 7-21, https://doi.org/10.1038/s41561-018-0262-x, 2019.

Binh, D. Van, Kantoush, S., and Sumi, T.: Changes to longterm discharge and sediment loads in the Vietnamese Mekong Delta caused by upstream dams, Geomorphology, 353, 107011, https://doi.org/10.1016/j.geomorph.2019.107011, 2020a.

Binh, D. Van, Kantoush, S. A., Saber, M., Mai, N. P., Maskey, S., Phong, D. T., and Sumi, T.: Long-term alterations of flow regimes of the Mekong River and adaptation strategies for the Vietnamese Mekong Delta, J. Hydrol. Reg. Stud., 32, 100742, https://doi.org/10.1016/j.ejrh.2020.100742, 2020b.

Binh, D. Van, Kantoush, S. A., Sumi, T., Mai, N. P., Ngoc, T. A., Trung, L. V., and An, T. D.: Effects of riverbed incision on the hydrology of the Vietnamese Mekong Delta, Hydrol. Process., 35, e14030, https://doi.org/10.1002/hyp.14030, 2021.

Bovee, K. D. and Scott, M. L.: Implications of flood pulse restoration forpopulus regeneration on the upper Missouri River, River Res. Appl., 18, 287-298, https://doi.org/10.1002/rra.672, 2002.

Bravard, J.-P., Goichot, M., and Gaillot, S.: Geography of Sand and Gravel Mining in the Lower Mekong River, EchoGéo, 26, https://doi.org/10.4000/echogeo.13659, 2013.

Bresney, S. R., Forni, L., Mautner, M. R. L., Huber-Lee, A., Shrestha, M., Moncada, A. M., Ghosh, E., and Sopharith, T.: Investigating Tradeoffs between Agricultural Devel- 
opment and Environmental Flows under Climate Change in the Stung Chinit Watershed, Cambodia, Hydrology, 7, 95, https://doi.org/10.3390/hydrology7040095, 2020.

Brunier, G., Anthony, E. J., Goichot, M., Provansal, M., and Dussouillez, P.: Recent morphological changes in the Mekong and Bassac river channels, Mekong delta: The marked impact of river-bed mining and implications for delta destabilisation, Geomorphology, 224, 177-191, https://doi.org/10.1016/j.geomorph.2014.07.009, 2014.

Bussi, G., Darby, S. E., Whitehead, P. G., Jin, L., Dadson, S. J., Voepel, H. E., Vasilopoulos, G., Hackney, C. R., Hutton, C., Berchoux, T., Parsons, D. R., and Nicholas, A.: Impact of dams and climate change on suspended sediment flux to the Mekong delta, Sci. Total Environ., 755, 142468, https://doi.org/10.1016/j.scitotenv.2020.142468, 2021.

Campbell, I. C., Say, S., and Beardall, J.: Tonle Sap Lake, the Heart of the Lower Mekong, in The Mekong, edited by: Campbell, I. C., Elsevier, 251-272, https://doi.org/10.1016/B978-0-12374026-7.00010-3, 2009.

Chen, A., Liu, J., Kummu, M., Varis, O., Tang, Q., Mao, G., Wang, J., and Chen, D.: Multidecadal variability of the Tonle Sap Lake flood pulse regime, Hydrol. Process., 35, e14327, https://doi.org/10.1002/hyp.14327, 2021.

Cochrane, T. A., Arias, M. E., and Piman, T.: Historical impact of water infrastructure on water levels of the Mekong River and the Tonle Sap system, Hydrol. Earth Syst. Sci., 18, 4529-4541, https://doi.org/10.5194/hess-18-4529-2014, 2014.

Cramb, R., Sareth, C., and Vuthy, T.: The Commercialisation of Rice Farming in Cambodia, in White Gold: The Commercialisation of Rice Farming in the Lower Mekong Basin, Springer Singapore, edited by: Cramb, R., Singapore, 227-245, https://doi.org/10.1007/978-981-15-0998-8_11, 2020.

Dang, T. D., Arias, M. E., Van, P. D., Vries, T. T., and Cochrane, T. A.: Analysis of water level changes in the Mekong floodplain impacted by flood prevention systems and upstream dams, in Eproceedings of the 36th IAHR World Congress, The Hague \& Delft, 28 June-3 July 2015, 7935, 2015.

Dang, T. D., Cochrane, T. A., Arias, M. E., Van, P. D. T., and de Vries, T. T.: Hydrological alterations from water infrastructure development in the Mekong floodplains, Hydrol. Process., 30, 3824-3838, https://doi.org/10.1002/hyp.10894, 2016.

Enomoto, K., Ishikawa, S., Hori, M., Sitha, H., Song, S. L., Thuok, N., and Kurokura, H.: Data mining and stock assessment of fisheries resources in Tonle Sap Lake, Cambodia, Fish. Sci., 77, 713722, https://doi.org/10.1007/s12562-011-0378-z, 2011.

Erban, L. E. and Gorelick, S. M.: Closing the irrigation deficit in Cambodia: Implications for transboundary impacts on groundwater and Mekong River flow, J. Hydrol., 535, 85-92, https://doi.org/10.1016/j.jhydrol.2016.01.072, 2016.

Fujii, H., Garsdal, H., Ward, P., Ishii, M., Morishita, K., and Boivin, T.: Hydrological roles of the Cambodian floodplain of the Mekong River, Int. J. River Basin Manag., 1, 253-266, https://doi.org/10.1080/15715124.2003.9635211, 2003.

Grundy-Warr, C. and Lin, S.: The unseen transboundary commons that matter for Cambodia's inland fisheries: Changing sediment flows in the Mekong hydrological flood pulse, Asia Pac. Viewp., 61, 249-265, https://doi.org/10.1111/apv.12266, 2020.
Guan, Y. and Zheng, F.: Alterations in the Water-Level Regime of Tonle Sap Lake, J. Hydrol. Eng., 26, 05020045, https://doi.org/10.1061/(ASCE)HE.1943-5584.0002013, 2021.

Hackney, C. R., Darby, S. E., Parsons, D. R., Leyland, J., Best, J. L., Aalto, R., Nicholas, A. P., and Houseago, R. C.: River bank instability from unsustainable sand mining in the lower Mekong River, Nat. Sustain., 3, 217-225, https://doi.org/10.1038/s41893019-0455-3, 2020.

Hackney, C. R., Vasilopoulos, G., Heng, S., Darbari, V., Walker, S., and Parsons, D. R.: Sand mining far outpaces natural supply in a large alluvial river, Earth Surf. Dynam., 9, 1323-1334, https://doi.org/10.5194/esurf-9-1323-2021, 2021.

Halls, A. S. and Hortle, K. G.: Flooding is a key driver of the Tonle Sap dai fishery in Cambodia, Sci. Rep.-UK, 11, 3806, https://doi.org/10.1038/s41598-021-81248-x, 2021.

Hecht, J. S., Lacombe, G., Arias, M. E., Dang, T. D., and Piman, T.: Hydropower dams of the Mekong River basin: A review of their hydrological impacts, J. Hydrol., 568, 285-300, https://doi.org/10.1016/j.jhydrol.2018.10.045, 2019.

Inomata, H. and Fukami, K.: Restoration of historical hydrological data of Tonle Sap Lake and its surrounding areas, Hydrol. Process., 22, 1337-1350, https://doi.org/10.1002/hyp.6943, 2008.

Ji, X., Li, Y., Luo, X., and He, D.: Changes in the Lake Area of Tonle Sap: Possible Linkage to Runoff Alterations in the Lancang River?, Remote Sens., 10, 866 , https://doi.org/10.3390/rs10060866, 2018.

Junk, W. J., Bayley, P. B., and Sparks, R. E.: The flood pulse concept in river-floodplain systems, Can. J. Fish. Aquat. Sci., 106, 110 127, 1989.

Kallio, M. and Kummu, M.: Comment on "Changes of inundation area and water turbidity of Tonle Sap Lake: responses to climate changes or upstream dam construction?", Environ. Res. Lett., 16, 058001, https://doi.org/10.1088/1748-9326/abf3da, 2021.

Kantoush, S., Binh, D. Van, Sumi, T., and Trung, L. V.: Impact of upstream hydropower dams and climate change on hydrodynamics of Vietnamese Mekong delta, J. Japan Soc. Civ. Eng. Ser. B1 (Hydraul. Eng.), 73, I_109-I_114, https://doi.org/10.2208/jscejhe.73.I_109, 2017.

Kea, S., Li, H., and Pich, L.: Technical Efficiency and Its Determinants of Rice Production in Cambodia, Economies, 4, 22 https://doi.org/10.3390/economies4040022, 2016.

Keovilignavong, O., Nguyen, T. H., and Hirsch, P.: Reviewing the causes of Mekong drought before and during 2019-20, Int. J. Water Resour. Dev., 1-21, https://doi.org/10.1080/07900627.2021.1967112, 2021.

Kondolf, G. M.: Hungry Water: Effects of Dams and Gravel Mining on River Channels, Environ. Manage., 21, 533-551, https://doi.org/10.1007/s002679900048, 1997.

Kondolf, G. M., Rubin, Z. K., and Minear, J. T.: Dams on the Mekong: Cumulative sediment starvation, Water Resour. Res., 50, 5158-5169, https://doi.org/10.1002/2013WR014651, 2014.

Kondolf, G. M., Schmitt, R. J. P., Carling, P., Darby, S., Arias, M., Bizzi, S., Castelletti, A., Cochrane, T. A., Gibson, S., Kummu, M., Oeurng, C., Rubin, Z., and Wild, T.: Changing sediment budget of the Mekong: Cumulative threats and management strategies for a large river basin, Sci. Total Environ., 625, 114-134, https://doi.org/10.1016/j.scitotenv.2017.11.361, 2018.

Kong, H., Chevalier, M., Laffaille, P., and Lek, S.: Spatio-temporal variation of fish taxonomic composition in a South-East Asian 
flood-pulse system, edited by: Hewitt, J., PLoS One, 12, e0174582, https://doi.org/10.1371/journal.pone.0174582, 2017.

Kummu, M. and Sarkkula, J.: Impact of the Mekong River Flow Alteration on the Tonle Sap Flood Pulse, Ambio, 37, 185-192, http://www.jstor.org/stable/25547881, 2008.

Kummu, M., Lu, X. X., Wang, J. J., and Varis, O.: Basinwide sediment trapping efficiency of emerging reservoirs along the Mekong, Geomorphology, 119, 181-197, https://doi.org/10.1016/j.geomorph.2010.03.018, 2010.

Kummu, M., Tes, S., Yin, S., Adamson, P., Józsa, J., Koponen, J., Richey, J., and Sarkkula, J.: Water balance analysis for the Tonle Sap Lake-floodplain system, Hydrol. Process., 28, 1722-1733, https://doi.org/10.1002/hyp.9718, 2014.

Li, D., Long, D., Zhao, J., Lu, H., and Hong, Y.: Observed changes in flow regimes in the Mekong River basin, J. Hydrol., 551, $217-$ 232, https://doi.org/10.1016/j.jhydrol.2017.05.061, 2017.

Lin, Z. and Qi, J.: Hydro-dam - A nature-based solution or an ecological problem: The fate of the Tonlé Sap Lake, Environ. Res., 158, 24-32, https://doi.org/10.1016/j.envres.2017.05.016, 2017.

Lu, X. X. and Chua, S. D. X.: River Discharge and Water Level Changes in the Mekong River: Droughts in an Era of Mega-Dams, Hydrol. Process., 35, e14265, https://doi.org/10.1002/hyp.14265, 2021.

Lu, X. X., Zhang, S. R., Xie, S. P., and Ma, P. K.: Rapid channel incision of the lower Pearl River (China) since the 1990s as a consequence of sediment depletion, Hydrol. Earth Syst. Sci., 11, 1897-1906, https://doi.org/10.5194/hess-11-1897-2007, 2007.

Lu, X. X., Li, S., Kummu, M., Padawangi, R., and Wang, J. J.: Observed changes in the water flow at Chiang Saen in the lower Mekong: Impacts of Chinese dams?, Quatern. Int., 336, 145-157, https://doi.org/10.1016/j.quaint.2014.02.006, 2014a.

Lu, X. X., Kummu, M., and Oeurng, C.: Reappraisal of sediment dynamics in the Lower Mekong River, Cambodia, Earth Surf. Proc. Land., 39, 1855-1865, https://doi.org/10.1002/esp.3573, 2014b.

Mahood, S. P., Poole, C. M., Watson, J. E. M., MacKenzie, R. A., Sharma, S., and Garnett, S. T.: Agricultural intensification is causing rapid habitat change in the Tonle Sap Floodplain, Cambodia, Wetl. Ecol. Manag., 28, 713-726, https://doi.org/10.1007/s11273-020-09740-1, 2020.

Mekong Region Futures Institute: Dataset on the Dams of the Greater Mekong, available at: https://wle-mekong.cgiar.org/ changes/our-research/greater-mekong-dams-observatory/ (last access: 1 July 2021), 2020.

Mekong River Commission: MRC time-series inventory, available at: https://portal.mrcmekong.org/home, last access: 1 July 2021.

Mekong River Commission: Regional Irrigation Sector Review for Joint Basin Planning Process, available at: https://www.mrcmekong.org/assets/Other-Documents/BDP/ BDP2-Irrigation-Sector-Review-Main-Report-Final-Mar2010. pdf (last access: 1 July 2021), 2009.

Mekong River Commission, Japan International Cooperation Agency, CTI Engineering International Co., Ltd., and Nippon Koei Co., L.: The Study on Hydro-meteorological Monitoring for Water Quantity Rules in Mekong River Basin, 2004.

$\mathrm{Ng}$, W. X. and Park, E.: Shrinking Tonlé Sap and the recent intensification of sand mining in the Cambodian Mekong River, Sci. Total Environ., 777, 146180, https://doi.org/10.1016/j.scitotenv.2021.146180, 2021.
Ngor, P. B., Grenouillet, G., Phem, S., So, N., and Lek, S.: Spatial and temporal variation in fish community structure and diversity in the largest tropical flood-pulse system of South-East Asia, Ecol. Freshw. Fish, 27, 1087-1100, https://doi.org/10.1111/eff.12417, 2018.

Oeurng, C., Cochrane, T., Chung, S., Kondolf, M., Piman, T., and Arias, M.: Assessing Climate Change Impacts on River Flows in the Tonle Sap Lake Basin, Cambodia, Water, 11, 618, https://doi.org/10.3390/w11030618, 2019.

Olson, K. R. and Morton, L. W.: Tonle Sap Lake and River and confluence with the Mekong River in Cambodia, J. Soil Water Conserv., 73, 60A-66A, https://doi.org/10.2489/jswc.73.3.60A, 2018.

Phengphaengsy, F. and Okudaira, H.: Assessment of irrigation efficiencies and water productivity in paddy fields in the lower Mekong River Basin, Paddy Water Environ., 6, 105-114, https://doi.org/10.1007/s10333-008-0108-z, 2008.

Piman, T., Cochrane, T. A., Arias, M. E., Green, A., and Dat, N. D.: Assessment of Flow Changes from Hydropower Development and Operations in Sekong, Sesan, and Srepok Rivers of the Mekong Basin, J. Water Resour. Plan. Manag., 139, 723-732, https://doi.org/10.1061/(ASCE)WR.1943-5452.0000286, 2013a.

Piman, T., Lennaerts, T., and Southalack, P.: Assessment of hydrological changes in the lower mekong basin from basinwide development scenarios, Hydrol. Process., 27, 2115-2125, https://doi.org/10.1002/hyp.9764, 2013b.

Raghavan, S. V, Liu, J., Nguyen, N. S., Vu, M. T., and Liong, S.-Y.: Assessment of CMIP5 historical simulations of rainfall over Southeast Asia, Theor. Appl. Climatol., 132, 989-1002, https://doi.org/10.1007/s00704-017-2111-z, 2018.

Räsänen, T. A. and Kummu, M.: Spatiotemporal influences of ENSO on precipitation and flood pulse in the Mekong River Basin, J. Hydrol., 476, 154-168, https://doi.org/10.1016/j.jhydrol.2012.10.028, 2013.

Räsänen, T. A., Koponen, J., Lauri, H., and Kummu, M.: Downstream Hydrological Impacts of Hydropower Development in the Upper Mekong Basin, Water Resour. Manag., 26, 3495-3513, https://doi.org/10.1007/s11269-012-0087-0, 2012.

Räsänen, T. A., Someth, P., Lauri, H., Koponen, J., Sarkkula, J., and Kummu, M.: Observed river discharge changes due to hydropower operations in the Upper Mekong Basin, J. Hydrol., 545, 28-41, https://doi.org/10.1016/j.jhydrol.2016.12.023, 2017.

Richter, B., Baumgartner, J., Wigington, R., and Braun, D.: How much water does a river need?, Freshwater Biol., 37, 231-249, https://doi.org/10.1046/j.1365-2427.1997.00153.x, 1997.

Royal Government of Cambodia: Policy Paper on The Promotion of Paddy Production and Rice Export, Phnom Penh, available at: http://extwprlegs1.fao.org/docs/pdf/cam189808.pdf (last access: 1 July 2021), 2010.

Sabo, J. L., Ruhi, A., Holtgrieve, G. W., Elliott, V., Arias, M. E., Ngor, P. B., Räsänen, T. A., and Nam, S.: Designing river flows to improve food security futures in the Lower Mekong Basin, Science, 358, eaao1053, https://doi.org/10.1126/science.aao1053, 2017.

Sakamoto, T., Van Nguyen, N., Kotera, A., Ohno, H., Ishitsuka, N., and Yokozawa, M.: Detecting temporal changes in the extent of annual flooding within the Cambodia and the Vietnamese Mekong Delta from MODIS time- 
series imagery, Remote Sens. Environ., 109, 295-313, https://doi.org/10.1016/j.rse.2007.01.011, 2007.

Schmitt, R. J. P., Rubin, Z., and Kondolf, G. M.: Losing ground - scenarios of land loss as consequence of shifting sediment budgets in the Mekong Delta, Geomorphology, 294, 58-69, https://doi.org/10.1016/j.geomorph.2017.04.029, 2017.

Siev, S., Yang, H., Sok, T., Uk, S., Song, L., Kodikara, D., Oeurng, C., Hul, S., and Yoshimura, C.: Sediment dynamics in a large shallow lake characterized by seasonal flood pulse in Southeast Asia, Sci. Total Environ., 631-632, 597-607, https://doi.org/10.1016/j.scitotenv.2018.03.066, 2018.

Singer, M. B.: The influence of major dams on hydrology through the drainage network of the Sacramento River basin, California, River Res. Appl., 23, 55-72, https://doi.org/10.1002/rra.968, 2007.

Singh, V. and Qin, X.: Study of rainfall variabilities in Southeast Asia using long-term gridded rainfall and its substantiation through global climate indices, J. Hydrol., 585, 124320, https://doi.org/10.1016/j.jhydrol.2019.124320, 2020.

Sithirith, M.: Water Governance in Cambodia: From Centralized Water Governance to Farmer Water User Community, Resources, 6, 44, https://doi.org/10.3390/resources6030044, 2017.

Sithirith, M.: Downstream state and water security in the mekong region: A case of cambodia between too much and too littlewater, Water, 13, 802, https://doi.org/10.3390/w13060802, 2021.

Soukhaphon, A., Baird, I. G., and Hogan, Z. S.: The Impacts of Hydropower Dams in the Mekong River Basin: A Review, Water, 13, 265, https://doi.org/10.3390/w13030265, 2021.

Stone, R.: Severe Drought Puts Spotlight on Chinese Dams, Science, 327, 1311-1311, https://doi.org/10.1126/science.327.5971.1311, 2010.

Thoeun, H. C.: Observed and projected changes in temperature and rainfall in Cambodia, Weather Clim. Extrem., 7, 61-71, https://doi.org/10.1016/j.wace.2015.02.001, 2015.

Tran, D. D. and Weger, J.: Barriers to Implementing Irrigation and Drainage Policies in An Giang Province, Mekong Delta, Vietnam, Irrig. Drain., 67, 81-95, https://doi.org/10.1002/ird.2172, 2018.

United Nations: UN Comtrade Database, available at: https:// comtrade.un.org (last access: 1 July 2021), 2017.

Västilä, K., Kummu, M., Sangmanee, C., and Chinvanno, S.: Modelling climate change impacts on the flood pulse in the Lower Mekong floodplains, J. Water Clim. Change, 1, 67-86, https://doi.org/10.2166/wcc.2010.008, 2010.
Vu, D. T., Yamada, T., and Ishidaira, H.: Assessing the impact of sea level rise due to climate change on seawater intrusion in Mekong Delta, Vietnam, Water Sci. Technol., 77, 1632-1639, https://doi.org/10.2166/wst.2018.038, 2018.

Wang, J.-J., Lu, X. X., and Kummu, M.: Sediment load estimates and variations in the Lower Mekong River, River Res. Appl., 27, 33-46, https://doi.org/10.1002/rra.1337, 2011.

Wang, Y., Feng, L., Liu, J., Hou, X., and Chen, D.: Changes of inundation area and water turbidity of Tonle Sap Lake: responses to climate changes or upstream dam construction? Environ. Res. Lett., 15, 0940a1, https://doi.org/10.1088/17489326/abac79, 2020.

$\mathrm{Yu}$, B. and Fan, S.: Rice production response in Cambodia, Agr. Econ., 42, 437-450, https://doi.org/10.1111/j.15740862.2010.00522.x, 2011.

Zhang, Q., Ye, X., Werner, A. D., Li, Y., Yao, J., Li, X., and Xu, C.: An investigation of enhanced recessions in Poyang Lake: Comparison of Yangtze River and local catchment impacts, J. Hydrol., 517, 425-434, https://doi.org/10.1016/j.jhydrol.2014.05.051, 2014.

Zhang, Z., Chen, X., Xu, C.-Y., Hong, Y., Hardy, J., and Sun, Z.: Examining the influence of river-lake interaction on the drought and water resources in the Poyang Lake basin, J. Hydrol., 522, 510-521, https://doi.org/10.1016/j.jhydrol.2015.01.008, 2015.

Ziv, G., Baran, E., Nam, S., Rodriguez-Iturbe, I., and Levin, S. A.: Trading-off fish biodiversity, food security, and hydropower in the Mekong River Basin, P. Natl. Acad. Sci. USA, 109, 56095614, https://doi.org/10.1073/pnas.1201423109, 2012.

Zoccarato, C., Minderhoud, P. S. J., and Teatini, P.: The role of sedimentation and natural compaction in a prograding delta: insights from the mega Mekong delta, Vietnam, Sci. Rep.-UK, 8, 11437, https://doi.org/10.1038/s41598-018-29734-7, 2018.

Zulkafli, Z., Buytaert, W., Manz, B., Rosas, C. V., Willems, P., Lavado-Casimiro, W., Guyot, J.-L., and Santini, W.: Projected increases in the annual flood pulse of the Western Amazon, Environ. Res. Lett., 11, 014013, https://doi.org/10.1088/17489326/11/1/014013, 2016. 